JOURNAL OF

ENVIRONMENTAL QUALITY

\title{
A national survey of trace organic contaminants in Australian rivers
}

\begin{tabular}{|r|l|}
\hline Journal: & Journal of Environmental Quality \\
\hline Manuscript ID: & JEQ-2014-01-0012-TR.R2 \\
\hline Manuscript Type: & Technical Research Paper \\
\hline Technical Report Subtypes: & Surface Water Quality \\
\hline Date Submitted by the Author: & 15-Jun-2014 \\
\hline Complete List of Authors: & $\begin{array}{l}\text { Scott, Phil } \\
\text { Bartkow, Michael } \\
\text { Blockwell, Stephen } \\
\text { Coleman, Heather } \\
\text { Khan, Stuart } \\
\text { Lim, Richard } \\
\text { McDonald, James } \\
\text { Nice, Helen } \\
\text { Nugegoda, Dayanthi } \\
\text { Pettigrove, Vincent } \\
\text { Tremblay, Louis } \\
\text { Warne, Michael } \\
\text { Leusch, Frederic; Griffith University, School of Environment }\end{array}$ \\
\hline Keywords: & \begin{tabular}{l} 
Hazard Quotient, Micropollutant, Surface Water, TrOC, Water Quality \\
\hline
\end{tabular} \\
\hline
\end{tabular}


1 A national survey of trace organic contaminants in Australian

3 Philip D. Scott ${ }^{\mathrm{a}}$, Michael Bartkow ${ }^{\mathrm{b}}$, Stephen J. Blockwell ${ }^{\mathrm{c}}$, Heather M. Coleman ${ }^{\mathrm{d}}$, Stuart J.

$4 \quad$ Khan $^{\mathrm{d}}$, Richard Lim ${ }^{\mathrm{e}}$, James A. McDonald ${ }^{\mathrm{d}}$, Helen Nice ${ }^{\mathrm{f}}$, Dayanthi Nugegoda ${ }^{\mathrm{g}}$, Vincent

5 Pettigrove ${ }^{\mathrm{h}}$, Louis A. Tremblay ${ }^{\mathrm{i}, \mathrm{j}}$, Michael St.J. Warne ${ }^{\mathrm{k}}$, and Frederic D.L. Leusch ${ }^{\mathrm{a}, *}$

$6{ }^{a}$ School of Environment, Griffith University, Southport, Queensland, 4222, Australia

$7 \quad$ b Seqwater, PO Box 16146, Brisbane City East, Queensland, 4002, Australia

$8 \quad{ }^{c}$ Sydney Water Corporation, PO Box 399, Parramatta, New South Wales, 2124, Australia

$9{ }^{\mathrm{d}}$ School of Civil \& Environmental Engineering, University of New South Wales, New South

10 Wales, 2052, Australia

11 e School of the Environment, University of Technology Sydney, PO Box 123, Broadway,

12 New South Wales, 2007, Australia

$13{ }^{\mathrm{f}}$ Water Science Branch, Department of Water, Government of Western Australia, PO Box

14 K822, Perth, Western Australia, 6842, Australia

$15 \mathrm{~g}$ School of Applied Sciences, Royal Melbourne Institute of Technology, PO Box 71,

16 Bundoora, Victoria, 3083, Australia

$17{ }^{\mathrm{h}}$ Melbourne Water, PO Box 4342, Melbourne, Victoria, 3001, Australia

$18{ }^{\mathrm{i}}$ Cawthron Institute, 98 Halifax Street East, Nelson, 7042, New Zealand

$19{ }^{\mathrm{j}}$ School of Biological Sciences, University of Auckland, PO Box 92019, Auckland, 1142,

20 New Zealand

$21{ }^{\mathrm{k}}$ Water Quality and Investigations, Department of Science, Information, Technology,

22 Innovation and the Arts, Queensland Government, GPO Box 5078, Brisbane, Queensland,

23 4001, Australia 


$\begin{array}{ll}24 & \text { * Corresponding Author. } \\ 25 & \text { e: } \underline{\text { f.leusch@ griffith.edu.au }} \\ 26 & \text { p: }+61755527832 \\ 27 & \text { Mailing address: } \\ 28 & \text { Dr Frederic Leusch } \\ 29 & \text { Smart Water Research Centre (G51) } \\ 30 & \text { Griffith University, Gold Coast Campus } \\ 31 & \text { Southport, Queensland, 4222 } \\ 32 & \text { Australia }\end{array}$

$34 \quad$ List of abbreviations

35 APCI Atmospheric Pressure Chemical Ionization

36 DEET N,N-Diethyl-meta-toluamide

37 ESI Electrospray Ionization

38 EU European Union

39 HPLC High Performance Liquid Chromatography

40 HQ Hazard Quotient

41 LC-MS/MS Liquid Chromatography Tandem Mass Spectrometry

42 LOQ Limit of Quantification

43 MRM Multiple Reaction Monitoring

44 NOEC No Observable Effect Concentration 
$45 \quad$ NSW

$46 \quad$ NT

$47 \quad \mathrm{PCP}$

48 PNEC

49 PPCP

50 QLD

51 SA

52 SEM

53 SPE

54 TCEP

55 TrOC

56 US

$57 \quad$ VIC

58 WA

59 WWTP
New South Wales (state of Australia)

Northern Territory (territory of Australia)

Personal Care Product

Predicted No Effect Concentration

Pharmaceutical and Personal Care Product

Queensland (state of Australia)

South Australia (state of Australia)

Standard Error of the Mean

Solid Phase Extraction

tris(2-Chloroethyl) Phosphate

Trace Organic Contaminant

United States

Victoria (state of Australia)

Western Australia (state of Australia)

Wastewater Treatment Plant

\section{Abstract}

62 Trace organic contaminant (TrOC) studies in Australia have focused on wastewater effluents,

63 leaving a knowledge gap of their occurrence and risk in freshwater environments. This study 
64 measured 42 TrOCs including industrial compounds, pesticides, pharmaceuticals and

65 personal care products (PPCPs) by liquid chromatography tandem mass spectrometry at 73

66 river sites across Australia quarterly for one year. TrOCs were found in $92 \%$ of samples, with

67 a median of three compounds detected per sample (maximum 18). The five most commonly

68 detected TrOCs were the pharmaceuticals salicylic acid ( $82 \% ; \max =1,530 \mathrm{ng} / \mathrm{L})$,

69 paracetamol (also known as acetaminophen; 45\%; $\max =7,150 \mathrm{ng} / \mathrm{L}$ ) and carbamazepine

$70 \quad(27 \% ; \max =682 \mathrm{ng} / \mathrm{L})$, caffeine $(65 \% ; \max =3,770 \mathrm{ng} / \mathrm{L})$, and the flame retardant $\operatorname{tris}(2-$

71 chloroethyl) phosphate (TCEP; 44\%; $\max =184 \mathrm{ng} / \mathrm{L})$. Pesticides were detected in $28 \%$ of

72 the samples. To determine the risk posed by the detected TrOCs to the aquatic environment,

73 hazard quotients were calculated by dividing the maximum concentration detected for each

74 compound by Predicted No Effect Concentrations (PNEC). Three of the 42 compounds

75 monitored (the pharmaceuticals carbamazepine and sulfamethoxazole and the herbicide

76 simazine) had a hazard quotient $>1$ suggesting that they may be causing adverse effects at the

77 most polluted sites. A further 10 compounds had hazard quotients $>0.1$ indicating a potential

78 risk; these included four pharmaceuticals, three personal care products and three pesticides.

79 Most compounds had hazard quotients significantly $<0.1$. The number of TrOCs measured in

80 this study was limited and further investigations are required to fully assess the risk posed by

81 complex mixtures of TrOCs on exposed biota.

\section{Keywords}

83 Hazard quotient; micropollutant; surface water; TrOC; water quality.

\section{1. Introduction}

86 With the human population surpassing seven billion, freshwater demand for municipal,

87 agricultural and industrial use has never been higher. There are over 100,000 registered 
chemicals in the European Union (EU) alone (Schwarzenbach et al. 2006) and recent improvements in analytical chemistry methodologies have enabled the study of trace organic contaminants (TrOCs) in freshwater at relevant environmental concentrations. There are over 4,000 pharmaceutical and personal care products (PPCPs) on the market (Boxall et al. 2012) and studies on their fate in the environment are lacking, along with an understanding of the nature and toxicity of their environmental transformation products (Brausch and Rand 2011, Fent et al. 2006). This is particularly the case in Australia (reviewed in Santos et al. 2010). A 2002 study detected 76 out of 95 wastewater-associated TrOCs monitored in 139 streams across the United States (US; Kolpin et al. 2002). A follow up study targeted 74 groundwater and surface water sources of drinking water for $100 \mathrm{TrOCs}$ and found at least one $\mathrm{TrOC}$ at 92\% of the sites (Focazio et al. 2008). These two nation-wide studies established TrOC concentration patterns across US impacted waterways. The first EU-wide assessment of TrOCs covered 122 surface water sites across 27 countries where $90 \%$ of the samples had a detection of at least one of the target TrOCs (Loos et al. 2009).

Australian research on TrOCs has predominantly focused on wastewater treatment plant (WWTP) processes and effluent rather than the receiving environment (Braga et al. 2005a, b, Chapman 2003, Coleman et al. 2008, Leusch et al. 2006, Mispagel et al. 2009, Williams et al. 2007, Ying et al. 2009). Khan and Ongerth (2004) used fugacity models to predict WWTP effluent concentrations of at least 50 pharmaceuticals and prioritised subsequent efforts for analytical investigation. A recent study of 39 Victorian WWTP effluents confirmed the presence of various TrOCs including PPCPs, pesticides, food additives and alkylphenols (Allinson et al. 2012). Concentrations were typically in the 1-1000 ng/L range but some compounds like carbamazepine were found above this range. Another study detected antibiotics in WWTP effluents at concentrations up to 3,400 ng/L, while rivers typically had low ng/L concentrations (but a maximum of 2,000 ng/L) (Watkinson et al. 2009). 
113 For this study, 285 grab water samples were collected from 73 river sites across Australia

114 every quarter over a one-year period. Samples were concentrated using solid phase extraction

115 (SPE) and specific TrOCs analyzed by liquid chromatography tandem mass spectrometry

116 (LC-MS/MS). The objective was to assess the risk of TrOCs to the environment by

117 determining their concentrations in impacted freshwater environments to better understand

118 the relationship between land-use activities and aquatic contamination.

\section{Experimental section}

\subsection{Site selection}

122 Sites were selected after extensive consultation with academics, regulators and water industry

123 partners. Sample locations consisted of 19 sites each in New South Wales (NSW),

124 Queensland (QLD), and Victoria (VIC), 10 sites in Western Australia (WA), and three sites

125 each in the Northern Territory (NT) and South Australia (SA) (Fig. 1). Sampling locations

126 (Fig. 1) reflect the fact that most Australians live in close proximity to the coast and the

127 center of the continent receives little rain. Sites were categorized based on the primary land-

128 use activity upstream in the catchment. Sites were rarely influenced by just one land-use and

129 so the dominant land-use dictated site categorization. Detailed catchment information can be

130 found in SI Table S1. Freshwater aquatic environments in catchments with agricultural,

131 industrial, residential and WWTP activities were selected, along with sites in catchments with

132 less anthropogenic influences (i.e., "undeveloped" or "reference" sites) from each

133 state/territory (Table 1). QLD consisted of five undeveloped sites, while NSW and VIC both

134 had three. NT, SA and WA had only one undeveloped site per territory/state. Other land-uses

135 had to be prioritized due to a smaller number of sampling locations.

136

137

[INSERT FIG 1 HERE] 
[INSERT TABLE 1 HERE]

140

141

\subsection{Water sampling}

142 Grab river water sampling started at the project commencement and samples were obtained

143 every three months, in Autumn (May 2011), Winter (August 2011), Spring (November 2011)

144 and Summer (February 2012) from each site (with the exception of NT sites, which were

145 only sampled twice, due to in-kind service personnel relocation) (Table 1). Two solvent-

146 rinsed $1 \mathrm{~L}$ amber glass bottles were submerged to approximately $20-30 \mathrm{~cm}$ depth in fast

147 flowing water as far towards the centre of the channel as possible from the water's edge in

148 order to collect $2 \mathrm{~L}$ grab water samples. To prevent biological degradation, $1.5 \mathrm{~mL}$ of $12 \mathrm{M}$

$149 \mathrm{HCl}$ (Merck, Victoria, Australia) was added to each bottle to lower the $\mathrm{pH}$ to approximately

150 2. Samples were packaged with ice blocks and sent by overnight courier to the laboratory for

151 solid-phase extraction (SPE). Geographic location and budgetary constraints made field

152 blanks unfeasible; however, one laboratory blank was generated for each sampling event.

\subsection{General water quality parameters}

155 Basic water chemistry (dissolved oxygen, electrical conductivity, $\mathrm{pH}$, temperature) was

156 measured in the field for each sample prior to acidification (SI Table S2). To minimize risk of

157 contamination, a small volume of water from each sample was decanted into a small vial for

158 determination of nitrate and nitrite concentrations with Hach AquaChek Nitrate Nitrite strips

159 (Notting Hill, Australia). Total chlorine, free chlorine, total hardness, total alkalinity and pH

160 were then measured using Hach AquaChek 5-in-1 strips (Notting Hill, Australia) following

161 the manufacturer's instructions (SI Table S2), and the decanted sample was discarded. 
162 Stream flow data were not available at the time of sampling; however, rainfall (and

163 atmospheric temperature) data were obtained for one week prior to sampling (SI Table S2).

\subsection{Solid-phase extraction (SPE)}

166 Upon arrival in the laboratory, water samples were adjusted to precisely $\mathrm{pH} 2 \mathrm{using} 12 \mathrm{M}$

$167 \mathrm{HCl}$ and extracted within $24 \mathrm{~h}$. Samples were vacuum filtered through $2 \mu \mathrm{m}$ glass fibre filters

168 (47 mm diameter; Millipore, Kilsyth, Australia). One L of sample was passed through a

169 preconditioned SPE cartridge (Oasis HLB SPE cartridges; 500 mg sorbent, 6 cc; Waters,

170 Rydalmere, Australia) at $10 \mathrm{~mL} / \mathrm{min}$. Cartridges were pre-conditioned with $2 \times 5 \mathrm{~mL}$ of

171 acetone: hexane (1: 1) (analytical reagent grade; Merck, Victoria, Australia) followed by $2 \times 5$

$172 \mathrm{~mL}$ methanol (analytical reagent grade; Labscan, Thailand) and finally $2 \times 5 \mathrm{~mL}$ distilled

173 water. After passing the full water sample, the SPE cartridges were dried under vacuum at 20

$174 \mathrm{mmHg}$ for $2 \mathrm{~h}$ (or until dry). Dried cartridges were wrapped in aluminium foil and stored at

$1754^{\circ} \mathrm{C}$ until elution (up to two weeks). A polar fraction was eluted with $2 \times 5 \mathrm{~mL}$ methanol and a

176 non-polar fraction was eluted with $2 \times 5 \mathrm{~mL}$ acetone: hexane (1: 1). This was repeated for the

177 second $1 \mathrm{~L}$ bottle. Fractions from both cartridges were combined and evaporated under

178 nitrogen until dry and immediately reconstituted into $1 \mathrm{~mL}$ methanol for chemical analysis.

179 One laboratory blank was generated for each sampling event.

\subsection{Liquid chromatography}

182 TrOCs were selected for monitoring based on their occurrence in WWTP effluents and 183 environmental waters, availability of deuterated standards and previously established 184 methods. Analytes were separated using an Agilent (Palo Alto, CA, USA) 1200 series high 185 performance liquid chromatography (HPLC) system equipped with a $150 \times 4.6 \mathrm{~mm}, 5 \mu \mathrm{m}$ 186 particle size, Luna C18(2) column (Phenomenex, Torrence CA, USA). A binary gradient 
187 consisting of $5 \mathrm{mM}$ ammonium acetate in water (A) and $100 \%$ methanol (B) at a flow rate of $188800 \mu \mathrm{L} / \mathrm{min}$ was used. For ESI positive analyses, the gradient was as follows: $10 \%$ B held for $1890.50 \mathrm{~min}$, stepped to $50 \% \mathrm{~B}$ at $0.51 \mathrm{~min}$ and increased linearly to $100 \% \mathrm{~B}$ at $8 \mathrm{~min}$, then held 190 at $100 \%$ B for 2 min. For ESI negative analyses, the gradient was as follows: $10 \%$ B held for $1910.50 \mathrm{~min}$, stepped to $60 \% \mathrm{~B}$ at $0.51 \mathrm{~min}$ and increased linearly to $100 \% \mathrm{~B}$ at $8 \mathrm{~min}$, then held 192 at $100 \%$ B for 3 min. A 5 min equilibration step at $10 \%$ B was used at the beginning of each 193 run. For APCI analysis the eluents consisted of milli-Q grade water (A) and $0.1 \% \mathrm{v} / \mathrm{v}$ formic 194 acid in methanol with the following ramp at a flow rate of $700 \mu \mathrm{L} / \mathrm{min}$ : $60 \%$ B held for 5 $195 \mathrm{~min}$, increased linearly to $100 \%$ B at $20 \mathrm{~min}$, then held at $100 \%$ B for $3 \mathrm{~min}$. A 3 min 196 equilibrium step preceded injection. An injection volume of $10 \mu \mathrm{L}$ was used for all methods. 197 Analytical methods using electrospray ionization (ESI) were based on Vanderford and 198 Snyder (2006).

2.6. Mass spectrometry

Mass spectrometry was performed using an API 4000 triple quadrupole mass spectrometer (Applied Biosystems, Foster City, CA, USA) equipped with a turbo-V ion source employed in both positive and negative electro-spray modes. Using multiple reaction monitoring (MRM), two mass transitions for all but three of the analytes were monitored for unequivocal confirmation. One mass transition for the labeled internal standard was monitored. Only the

206 first transition was used for quantification. Relative retention times of the analyte and isotopically labeled internal standard were also monitored to ensure correct identification. A table of transitions can be found in the Supplementary Information (SI Tables S3 and S4). 
211 Standard solutions of all analytes were prepared at 1, 5, 10, 50, 100, 500 and $1000 \mathrm{ng} / \mathrm{mL}$. A

212 relative response ratio of analyte/ internal standard over a 1-1000 ng concentration range was

213 generated enabling quantitation with correction for losses due to ion suppression. All

214 calibration curves had a correlation coefficient of 0.99 or better. The limits of quantification

215 (LOQs) were determined as an s/n ratio greater than 10.

\subsection{Statistical analysis}

218 When required, statistical analysis was performed using the Kruskal-Wallis nonparametric test, followed by Dunn's multiple comparison test, on Prism 5 software (GraphPad Software, California, USA).

\section{Results and discussion}

\subsection{Chemical analysis}

224 The monitored TrOCs were found in $92 \%$ of samples, with a median of three compounds 225 detected per sample (maximum of 18). In contrast, Kolpin et al. (2002) reported a median of seven chemical detects per sample and a maximum of 38 (out of 95) in a study that investigated many overlapping chemical classes. Focazio et al. (2008) indicated that a median of four chemicals detected per sample, with a maximum of 31 (out of 100) in surface water and groundwater. These studies used LC-MS with detections typically between 10-500 ng/L.

230 The most chemically diverse sample had $45 \%$ of the targeted compounds compared to $40 \%$ found in a US study (Kolpin et al. 2002). However, a subsequent US-based surface water and groundwater study reported $63 \%$ of targeted TrOCs present in the most chemically complex sample (Focazio et al. 2008). Overall, the six most frequently detected compounds in this study were salicylic acid (82\%), caffeine (65\%; not analyzed in Spring sampling), 
235 paracetamol (also known as acetaminophen; 45\%; not analyzed in Spring sampling), TCEP

$236(44 \%)$, carbamazepine (27\%) and triclosan (25\%). Four compounds were detected at least

237 once at concentrations in excess of $1,000 \mathrm{ng} / \mathrm{L}$ : paracetamol $(7,200 \mathrm{ng} / \mathrm{L})$, simazine $(3,900$

$238 \mathrm{ng} / \mathrm{L})$, caffeine (3,800 ng/L) and salicylic acid (1,500 ng/L).

239

240

[INSERT FIG 2 HERE]

241

242

[INSERT TABLE 2 HERE]

243

244

[INSERT TABLE 3 HERE]

245

246

\subsubsection{Land-use}

247 The analytical methods were initially developed for wastewater contaminants such as

248 pharmaceuticals and personal care products (PPCPs). Of the five land-uses targeted, samples

249 collected downstream of WWTPs ( $\mathrm{n}=50$ out of 285) had the highest median number of

250 detections with 7 chemicals per sample (average $=6.5$ ) although this was not significantly

251 different (Kruskal-Wallis test; $\mathrm{p}>0.05$ ) from industrial, residential, or agricultural samples.

252 Industrial $(n=28)$, residential $(n=74)$ and agricultural $(n=80)$ samples had medians of 6,4 and

2532 TrOCs per sample, respectively (averages of 6.2, 4.3 and 2.6 TrOCs respectively). Finally,

254 undeveloped sites had the lowest number of TrOCs with an average of 1.5 per sample

255 (median $=1)$; this value was significantly different (Kruskal-Wallis test; $\mathrm{p}<0.05)$ from other

256 land-uses. These results indicate that TrOCs are widespread across land-uses and not simply

257 in rivers receiving WWTP discharges. This may be due to the presence of septic tank

258 systems, leaking sewer lines, the result of combined sewer overflows into waterways 
259 following intense wet weather events, or some other unknown source. There is clearly a need

260 for further research investigating TrOCs from other land-uses activities.

261 Fig. 2 (top) indicates that the top five most frequently detected compounds did not vary

262 greatly across the different land-uses. The most frequently detected TrOCs were: salicylic

263 acid, caffeine, paracetamol, TCEP, carbamazepine, triclosan, 2-phenylphenol and

264 propylparaben (Tables 2 and 3). Of those, salicylic acid (64-100\%) and caffeine (34-90\%)

265 were in the top five compounds for all land-use categories (Fig. 2, top). Caffeine is a common

266 wastewater contaminant and has occasionally been used as a marker compound for human

267 wastewater (Metcalfe et al. 2003). The prevalence of caffeine and PPCPs suggests

268 widespread (but low) wastewater pollution, from an unknown source(s), possibly septic tank

269 leakage, or sewage overflow during heavy rainfall, which was common in the sampling

270 period (SI Table S2).

271

272 3.1.2. Location

273 Geographic location (Fig. 1, SI Table S2) was used to sort number of TrOCs per sample by 274 Australian state or territory. Samples from NT $(n=6)$ had the highest average number of 275 detections per sample (6.5 compounds per sample). NSW (n=76) had 4.4, WA $(n=40)$ had 276 4.3, SA $(n=12)$ had 4.2, and VIC $(n=76)$ had 4.1 detections per sample. QLD samples $(n=75)$

277 had the lowest national average with 2.7 compounds detected per sample.

278 Salicylic acid was the most frequently detected compound in each state (Fig. 2, bottom) and 279 detection frequencies varied from $61 \%$ in QLD to $100 \%$ in SA. It was interesting to see that 280 salicylic acid was one of the most commonly detected compounds despite its relatively high 281 LOQ.

282

283

\subsubsection{Seasonal and land-use trends}


284 Qualitative assessment of the dataset indicated that most analytes had similar frequencies of 285 detection throughout all four sampling events with a few exceptions (Table 2). Primidone 286 was detected more frequently in Autumn (May-2011) and Spring (Nov-2011), compared to 287 Winter (Aug-2011) and Summer (Feb-2012). Phenytoin was found consistently in Autumn, 288 Winter and Spring (11, 15 and 13 times, respectively), but not once in Summer.

289 Propylparaben was detected 23 times in Spring, but not as often in other sampling events (0 290 times in Autumn; 3 times in Winter; 8 times in Summer). The biocide 2-phenylphenol was 291 only identified twice each in Autumn and Winter, seven times Spring, and 27 times in the 292 Summer. Australia, a continent the size of Europe, experiences vast climatic and seasonal differences between states/territories and even between sites within states/territories. Temperature can significantly influence WWTP removal efficiencies of TrOCs (Ternes et al. 1999), and rainfall can impact their dilution in receiving environments (Ternes 1998). Analysis of chemical data sub-divided by land-use did not indicate any trends. Sites were categorized based on the most influential point (e.g. WWTP) or non-point sources (e.g. agricultural, industrial, or residential) and many had influence from multiple land-use categories. The data suggest that the water quality does not necessarily reflect the dominant proximal land-use influence.

\subsubsection{Pharmaceuticals.}

303 Six pharmaceuticals were detected in more than $10 \%$ of samples: salicylic acid (82\%), paracetamol (45\%), carbamazepine (27\%), primidone (14\%), phenytoin (14\%) and gemfibrozil (11\%). Nine pharmaceuticals were never detected (Table 2) and paracetamol and salicylic acid were detected at concentrations above 1,000 ng/L.

307 Salicylic acid, the most frequently detected compound, is an important metabolite of 308 acetylsalicylic acid (aspirin), but is also a plant hormone and can be found in many species, 
309 most notably in willow tree bark (Krantz et al. 2010, National Center for Biotechnology

310 Information 1999). Willows are a pest species in many Australian waterways and may partly

311 explain the broad presence of salicylic acid in this study. Salicylic acid is relatively non-toxic

312 to aquatic wildlife with a predicted no effect concentration (PNEC) usually ranging from

$31360,000-170,000 \mathrm{ng} / \mathrm{L}$ (Schowanek and Webb 2002, Wang et al. 2010), and the

314 concentrations reported here represent a negligible risk. Many metabolites and degradation

315 products exhibit toxicological effects (Lambropoulou and Nollet, 2014), so further research

316 into these chemical products is required.

317 Paracetamol was detected in $45 \%$ of the samples, with a maximum of $7,150 \mathrm{ng} / \mathrm{L}$ (the highest

318 concentration in this entire study). In two USA studies, maximum concentrations ranged

319 from 160-10,000 ng/L (Focazio et al. 2008, Kolpin et al. 2002). With a PNEC of 9,200 ng/L

320 (Schowanek and Webb 2002), our data suggests that paracetamol represents a low risk in

321 Australian rivers, although it should be highlighted that the highest concentration detected

322 provided only a narrow margin of safety (Table 3 ).

323 The next most common pharmaceutical was carbamazepine, an anticonvulsant, with a

324 frequency of $27 \%$ and a maximum of $682 \mathrm{ng} / \mathrm{L}$ (Table 3). In a USA surface water and

325 groundwater study, the frequency of detection was $22 \%$ and the maximum concentration was

$326200 \mathrm{ng} / \mathrm{L}$ (Focazio et al. 2008). However, in an EU-wide study of surface waters,

327 carbamazepine was detected more frequently (95\%) with a maximum concentration $\sim 20 \times$

328 higher (Loos et al. 2009). Carbamazepine was one of five most frequently detected

329 compounds in each land-use category, except for undeveloped. It was found most commonly

330 in NSW and VIC. The PNEC for carbamazepine is $500 \mathrm{ng} / \mathrm{L}$ (Agerstrand and Ruden 2010),

331 suggesting that while there is little cause for concern in most situations, carbamazepine may

332 pose a risk to the receiving environment at some sites (carbamazepine was above $500 \mathrm{ng} / \mathrm{L}$ in

333 five out of 285 measurements, i.e., 1.7\% of samples). Phenytoin (an antiepileptic also known 
334 as dilantin) and primidone (an anticonvulsant) had maximum concentrations of 145 and 259

$335 \mathrm{ng} / \mathrm{L}$, respectively (Table 3). In four USA streams, concentrations of phenytoin ranged from

336 3.7-391 ng/L (Snyder et al. 2007), while the maximum concentration in Japanese river water

337 was $51 \mathrm{ng} / \mathrm{L}$ (Komori et al. 2013). Primidone was found in 10 German rivers at

338 concentrations ranging from 10-594 ng/L, but typical concentrations were $>300 \mathrm{ng} / \mathrm{L}$

339 (Hummel et al. 2006). In Japan, primidone was detected with a maximum concentration of 38

$340 \mathrm{ng} / \mathrm{L}$ (Komori et al. 2013). Both phenytoin and primidone are relatively non-toxic to aquatic

341 organisms with PNECs of $>100,000 \mathrm{ng} / \mathrm{L}$ (Komori et al. 2013), suggesting that the

342 concentrations found in this study are unlikely to be of environmental concern.

343 Gemfibrozil (an antiepileptic; $\mathrm{LOQ}=5 \mathrm{ng} / \mathrm{L}$ ) had a maximum concentration of $213 \mathrm{ng} / \mathrm{L}$ and

344 a detection frequency of $11 \%$ (Table 3 ). In comparison, it was detected $3.5 \%$ of the time in

345 one US-wide study (with a maximum concentration of $790 \mathrm{ng} / \mathrm{L} ; \mathrm{LOQ}=15 \mathrm{ng} / \mathrm{L}$ ) (Kolpin et

346 al. 2002), and not at all in a follow-up study (LOQ = $15 \mathrm{ng} / \mathrm{L}$; Focazio et al. 2008). However,

347 gemfibrozil was found more frequently in a European study (35\%; LOQ = $1 \mathrm{ng} / \mathrm{L})$, which

348 also reported a higher maximum concentration of $900 \mathrm{ng} / \mathrm{L}$ (Loos et al. 2009). While the

349 maximum concentration is less than in other studies, the detection frequency is in a similar

350 range. With a PNEC of 1,000 ng/L (Wang et al. 2010), the concentrations detected here

351 represent negligible risk.

352 Sulfamethoxazole, an antibiotic often used in combination with trimethoprim (another

353 antibiotic), was detected in nine percent of samples, with a maximum concentration of 67

$354 \mathrm{ng} / \mathrm{L}$ (Table 3). Four samples had concentrations that exceeded the PNEC of $26.8 \mathrm{ng} / \mathrm{L}$

355 (Agerstrand and Ruden 2010), while two additional samples were close. Further effects

356 monitoring at the most polluted sites would help assess the environmental risk of

357 sulfamethoxazole. 
358 Although trimethoprim was only detected in 5\% of samples, it was present at the sixth overall

359 highest concentration (657 ng/L; Table 3). It was detected more frequently (12.5\%) and had a

360 higher maximum concentration of $710 \mathrm{ng} / \mathrm{L}$ in a US study (Kolpin et al. 2002). However,

361 another US study had a much lower maximum concentration (20 ng/L) (Focazio et al. 2008).

362 With a comparatively high PNEC of 180,000 ng/L (Halling-Sorensen et al. 2000), the

363 concentrations of trimethoprim detected here are unlikely to cause direct environmental

364 effects, however indirect antibiotic resistance could be a potential problem.

365

366

\subsubsection{Personal care products (PCPs)}

367 Caffeine was the most commonly detected PCP, occurring in $65 \%$ of samples, followed by 368 triclosan (25\%) and propylparaben (12\%). Caffeine was the second most common TrOC in

369 this study (median $=19 \mathrm{ng} / \mathrm{L})$ and had the third highest reported concentration overall $(3,770$

$370 \mathrm{ng} / \mathrm{L}$; Table 3). The maximum concentration was measured in a NSW industrial sample.

371 There were seven other samples with caffeine concentrations above 1,000 ng/L; four

372 residential, three industrial and one WWTP samples. The maximum concentration of caffeine

373 falls between that reported in Focazio et al. (2008) (270 ng/L) and Kolpin et al. (2002) (6,000

$374 \mathrm{ng} / \mathrm{L})$. All three mentioned maximums fall significantly short of $39,813 \mathrm{ng} / \mathrm{L}$ reported in a

375 European surface water sample (Loos et al. 2009). The frequency of detection for caffeine

376 corresponded closely with that reported in Kolpin et al (2002) (71\%). With a PNEC for

377 caffeine of 5,200 ng/L (Komori et al. 2013), caffeine generally poses a low risk, although it

378 should be noted that some of the data points above $1,000 \mathrm{ng} / \mathrm{L}$ only leave a slim margin of

379 safety.

380 Triclosan, a widely used broad spectrum antibacterial compound, was the second most

381 commonly detected PCP (25\%), with a maximum concentration of $87 \mathrm{ng} / \mathrm{L}$. Kolpin et al.

382 (2002) detected triclosan in $57 \%$ of samples with a maximum concentration of 2,300 ng/L 
and a median concentration of $140 \mathrm{ng} / \mathrm{L}$. Triclosan was also found in wild fish in WWTP effluent receiving environments in Sweden at concentrations up to $0.90 \mathrm{mg} / \mathrm{kg}$ fresh weight of bile (Adolfsson-Erici et al. 2002). New evidence suggests that the risk from exposure to triclosan could be underestimated and as such, the PNEC of $500 \mathrm{ng} / \mathrm{L}$ (Perez et al. 2013) may not be adequate. For instance, triclosan was found to negatively affect larval fathead minnow (Pimephales promelas) swimming performance at $151 \mathrm{ng} / \mathrm{L}$, an exposure concentration less than twice the maximum concentration reported herein (87 ng/L; Table 3; Cherednichenko et al. 2012). Drury et al. (2013) reported that sediment triclosan concentrations (a maximum concentration of $107 \pm 18 \mathrm{ng} / \mathrm{g}$ ) were directly proportional to the relative abundance of resistant bacteria. In light of this information, some triclosan concentrations in Australian rivers may pose considerable risk to aquatic organisms.

Propylparaben which is both a natural substance and a PCP, was the third most commonly detected PCP (12\%) with a maximum concentration of $218 \mathrm{ng} / \mathrm{L}$ (Table 3). The maximum concentration reported is much less than that found in Spanish surface waters $(32,000 \mathrm{ng} / \mathrm{L})$ (Regueiro et al. 2009), while another Spanish study did not detect propylparaben in surface waters ( $<5 \mathrm{ng} / \mathrm{L})($ Pedrouzo et al. 2009). A UK study reported a maximum concentration of $11 \mathrm{ng} / \mathrm{L}$ in surface waters (Kasprzyk-Hordern et al. 2008). With a PNEC of approximately 20,000 ng/L (Yamamoto et al. 2011), the risk of propylparaben to the Australian aquatic environment appears negligible.

Triclocarban, used as an anti-bacterial and anti-fungal disinfectant in soaps and other household products, was detected in one percent of the samples, with a maximum concentration of $58 \mathrm{ng} / \mathrm{L}$. A PNEC of $190 \mathrm{ng} / \mathrm{L}$ was recently derived for triclocarban (Tamura et al. 2012). A LOEC of $130 \mathrm{ng} / \mathrm{L}$ (NOEC of $60 \mathrm{ng} / \mathrm{L}$ ) was previously reported for Mysidopsis bahia reproduction rate (U.S. Environmental Protection Agency 2008). There is limited information about the occurrence of triclocarban in the environment in general, 
408 compared to triclosan. Halden and Paull (2005) predicted mean and median concentrations of

409213 and $109 \mathrm{ng} / \mathrm{L}$, respectively, in US streams, which warrants further chemical monitoring

410 efforts.

411 DEET was analyzed but results were not presented due to concerns that some LC-MS/MS

412 methods, including ours, may overestimate DEET concentrations due to an unidentified

413 natural substance that is being incorrectly measured as DEET (Snyder, pers. comm.). A more

414 robust chemical analysis methodology for DEET may be required to accurately quantify this

415 compound in the environment.

416

417 3.1.6. Industrial compounds

418 The flame retardant TCEP was the only industrial compound examined. TCEP was detected

419 in $44 \%$ of samples, with a maximum concentration of $184 \mathrm{ng} / \mathrm{L}$ (detected in a SA sample

420 downstream of a WWTP; Table 3). Similarly, Kolpin et al. (2002) detected TCEP in 60\% of

421 samples, but reported significantly higher maximum and median concentrations $(54,000$

$422 \mathrm{ng} / \mathrm{L}, 100 \mathrm{ng} / \mathrm{L})$. Focazio et al. (2008) detected TCEP in $20 \%$ of samples, but concentrations

423 were less than the quantification limit (500 ng/L). Mean and maximum concentrations of 203

$424 \mathrm{ng} / \mathrm{L}$ and 2,019 ng/L, respectively, were found in five German rivers (Quednow and

425 Puttmann 2009). While it was frequently detected, TCEP poses a negligible risk considering

426 its PNEC of 65,000 ng/L (Quednow and Puttmann 2009).

428 3.1.7. Pesticides

429 Pesticides were not commonly detected in our water samples. As of 2002, simazine (LOQ = 5

$430 \mathrm{ng} / \mathrm{L})$ and atrazine (LOQ $=5 \mathrm{ng} / \mathrm{L})$ were the most widely used herbicides in Australia

431 (Radcliffe, 2002), however they were only detected in $14 \%$ and $11 \%$ of samples,

432 respectively. The fungicide 2-phenylphenol (LOQ = $10 \mathrm{ng} / \mathrm{L}$ ) was detected in $13 \%$ of 
433 samples, although it was not among the most frequently used fungicides in Australia

434 (Radcliffe 2002). Linuron (LOQ = $5 \mathrm{ng} / \mathrm{L}$ ), which has the same mode of action as atrazine 435 and simazine, has also been used frequently in Australia, but was only detected in three 436 percent of samples; predominantly in agricultural samples (66\% of detections). Chlorpyrifos $437(\mathrm{LOQ}=5 \mathrm{ng} / \mathrm{L})$ and diazinon $(\mathrm{LOQ}=5 \mathrm{ng} / \mathrm{L})$ have been the most widely used insecticides in 438 Australia (Radcliffe, 2002); but despite its wide use, chlorpyrifos was detected only twice at 439 very low concentrations ( $5 \mathrm{ng} / \mathrm{L})$ and diazinon was never detected. Trifluralin was not 440 detected either (LOQ $=150 \mathrm{ng} / \mathrm{L})$, despite its wide use as a pre-emergent control for weeds 441 (Radcliffe, 2002). It is, however, important to note that chlorpyrifos, diazinon and trifluralin were only analyzed in the Spring sampling event.

443 Simazine had a maximum concentration of 3,930 ng/L (Table 3), which exceeded the PNEC 444 of $3,200 \mathrm{ng} / \mathrm{L}$ derived using the $95^{\text {th }}$ percentile and may pose a risk (ANZECC/ARMCANZ 445 2000). However it should be noted that it was only exceeded in one sampling event. The 446 maximum concentration was also higher than those found in different studies in Australia, the 447 US and Europe. An Australian study of 39 WWTP effluents reported a maximum 448 concentration for simazine of 1,727 ng/L (Allinson et al. 2012). A European survey of river waters reported a detection frequency of $26 \%$, a maximum concentration of $169 \mathrm{ng} / \mathrm{L}$ and an average concentrations of $10 \mathrm{ng} / \mathrm{L}$ (Loos et al. 2009). An EU ground water survey reported a

451 higher detection frequency of $43 \%$ but a lower maximum concentration of $127 \mathrm{ng} / \mathrm{L}$ and an 452 average of $7 \mathrm{ng} / \mathrm{L}$ (Loos et al. 2010). In a US shallow groundwater study of 1,034 sites, 453 simazine had a detection frequency of $18 \%$ and a maximum concentration of $1,300 \mathrm{ng} / \mathrm{L}$ 454 (Kolpin et al. 1998), while a surface water study including 151 water samples from 71 455 streams (and five reservoirs) detected simazine in $7-47 \%$ of samples (depending on sample 456 type) and a maximum concentration of $14,150 \mathrm{ng} / \mathrm{L}$, while median concentrations were all 457 below the reporting limit (<50 ng/L; Battaglin et al. 2003). 
458 The maximum concentration for 2-phenylphenol $(92 \mathrm{ng} / \mathrm{L})$ occurred in a sample collected

459 downstream of a WWTP in VIC. This concentration was lower than the sole concentration 460 measured from 39 different WWTP effluent samples in the same state (240 ng/L) (Allinson et

461 al. 2012). A PNEC of $900 \mathrm{ng} / \mathrm{L}$ was determined using a reproduction test with Daphnia

462 magna (Bayer 2001), which results in a Hazard Quotient (HQ) of 0.1 for 2-phenylphenol.

463 This indicates that there may be cause for concern at the maximum concentration.

464 Atrazine was detected in $11 \%$ of samples, with a maximum concentration of $209 \mathrm{ng} / \mathrm{L}$ (Table

465 3). Kolpin et al. (1998) reported a much higher detection frequency (38\%) and maximum

466 concentration $(3,600 \mathrm{ng} / \mathrm{L})$. In Europe, a detection frequency of $68 \%$, a maximum

467 concentration of $46 \mathrm{ng} / \mathrm{L}$ and an average concentration of $3 \mathrm{ng} / \mathrm{L}$ were reported in surface

468 waters (Loos et al. 2009). Atrazine was detected in 56\% of groundwater samples in Europe

469 with a maximum concentration of $253 \mathrm{ng} / \mathrm{L}$ and an average of $8 \mathrm{ng} / \mathrm{L}$ (Loos et al. 2010).

470 Atrazine was detected twice in WWTP effluents from across VIC with a maximum

471 concentration of $63 \mathrm{ng} / \mathrm{L}$ (Allinson et al. 2012). Interestingly, Australian WWTP effluent

472 contained less atrazine than river waters investigated in this study, again clearly indicating

473 that pesticides are likely to be attributable to other activities (such as agriculture, road

474 maintenance, etc). Atrazine has a PNEC of 13,000 ng/L (ANZECC/ARMCANZ 2000) and as

475 such, the maximum concentration of $209 \mathrm{ng} / \mathrm{L}$ is unlikely to be cause for concern, although

476 sampling design did not take into account run-off events, when environmental concentrations

477 could be elevated. Furthermore, there is still a vigorous scientific debate about its potential

478 endocrine effects (APVMA 2008).

479 It should be noted that we only measured a small number of pesticides, and that there is a

480 large and growing body of literature on many different types of pesticides detected in

481 Australian rivers (e.g., Allinson et al. 2012; Church et al. 2004; Davis et al. 2008; Lewis et al.

482 2009; Sanchez-Bayo and Hyne 2014; Schäfer et al. 2011). 


\section{3.2. Conclusions}

485 A median of three TrOCs out of 42 was detected per sample, with a maximum of 18 . The six 486 most frequently detected compounds in this study were: salicylic acid (82\%), caffeine (65\%), 487 paracetamol (45\%), TCEP (44\%), carbamazepine (27\%) and triclosan (25\%). Most 488 pharmaceutical detected were at concentrations posing negligible risk. However, 489 carbamazepine and sulfamethoxazole exceeded their PNECs five and four times each, 490 respectively. Maximum concentrations of other pharmaceuticals (fluoxetine, gemfibrozil, 491 naproxen, paracetamol) and PCPs (caffeine, triclocarban and triclosan) left only small 492

\subsection{Limitations and future research}

The PNEC values used to calculate Hazard Quotients (HQs) and margins of safety were based on international studies, and it is unclear at this stage whether those levels would protect the unique Australian wildlife. Further work is needed to establish PNECs specific to

501 the Australian environment.

502 The analytical issues with DEET and salicylic acid need to be overcome in the future to 503 determine the actual impact that anthropogenic use of these chemicals have on the 504 environment. This study relied on grab sampling, and further studies with composite or 505 passive sampling techniques may provide a better measure of concentrations over longer time 506 windows. 
507 This study measured "only" 42 TrOCs and many more are likely present in the Australian

508 environment, including environmental transformation products. While most compounds were

509 present below PNEC values, their potential for interaction and mixture toxicity needs to be

510 investigated using effects based assessment (e.g., using in vitro and in vivo techniques).

511 Finally, in situ studies at the most polluted sites identified would help determine if the PNEC

512 exceedances reported lead to significant environmental disturbances.

514 Acknowledgment

515 The authors gratefully acknowledge the assistance of E. Prochazka and T. Teo for their

516 laboratory analysis, and M. Allinson, J. Blackbeard, S. Codi-King, H. Chapman, A. Colville,

517 D. Gale, B. Harper, M. Mortimer, and T. Reitsema for their input in planning and

518 implementation during this project. Sampling could not have been completed without the

519 dedication of many industry partners, whose support we are very grateful for. This study was

520 funded by the Australian Research Council (ARC Linkage scheme LP100100163) in

521 collaboration with Water Research Australia, Sydney Water, Seqwater and Melbourne Water,

522 and supported in-kind by the Queensland Department of Science, Information, Technology,

523 Innovation and the Arts (DSITIA) and the Western Australia Department of Water. P.S. was

524 supported with an Australian Postgraduate Award (Industry) scholarship and Water Research

525 Australia PhD top-up scholarship.

\section{References}

528 Adolfsson-Erici, M., Pettersson, M., Parkkonen, J. and Sturve, J. 2002. Triclosan, a

529 commonly used bactericide found in human milk and in the aquatic environment in

$530 \quad$ Sweden. Chemosphere 46(9-10), 1485-1489. 
531 Agerstrand, M. and Ruden, C. 2010. Evaluation of the accuracy and consistency of the

532 Swedish Environmental Classification and Information System for pharmaceuticals.

$533 \quad$ Sci. Total Environ. 408(11), 2327-2339.

534 Allinson, M., Kageyama, S., Nakajima, D., Kamata, R., Shiraishi, F., Goto, S., Salzman, S.A.

535 and Allinson, G. 2012. A pilot survey of 39 Victorian WWTP effluents using a high

536 speed luminescent umu test in conjunction with a novel GC-MS-database technique for

537 automatic identification of micropollutants. Water Sci. Technol. 66(4), 768-774.

538 ANZECC/ARMCANZ. 2000. Australian guidelines for water quality monitoring and

539 reporting, Agriculture and Resource Management Council of Australia and New

540 Zealand, Agriculture and Resource Management Council of Australia and New

$541 \quad$ Zealand, Canberra, ACT, Australia.

542 APVMA. 2008. Atrazine final review report and regulatory decision. Australian Pesticides \&

$543 \quad$ Veterinary Medicines Authority, Australia Capital Territory.

544 Australian Bureau of Statistics. 2012. Report 3218.0 Regional population growth, Australia,

545 2012, Commonwealth of Australia, Canberra.

546 Battaglin, W.A., E.M. Thurman, S.J. Kalkhoff and S.D. Porter. 2003. Herbicides and

547 transformation products in surface waters of the midwestern United States. Journal of

548 the American Water Resources Association 39. doi:10.1111/j.1752-

$549 \quad$ 1688.2003.tb04402.x.

550 Bayer, A.G. 2001. Report on Preventol O extra Daphnia magna reproduction test (OECD

551 211), Report No. 1092A/01/DL.

552 Boxall, A.B.A., Rudd, M.A., Brooks, B.W., Caldwell, D.J., Choi, K., Hickmann, S., Innes,

553 E., Ostapyk, K., Staveley, J.P., Verslycke, T., Ankley, G.T., Beazley, K.F., Belanger,

554 S.E., Berninger, J.P., Carriquiriborde, P., Coors, A., DeLeo, P.C., Dyer, S.D., Ericson,

555 J.F., Gagne, F., Giesy, J.P., Gouin, T., Hallstrom, L., Karlsson, M.V., Larsson, D.G.J., 
556

557

558

559

560

561

562

563

564

565

566

567

568

569

570

571

572

573

574

575

576

577

578

579

580

Lazorchak, J.M., Mastrocco, F., McLaughlin, A., McMaster, M.E., Meyerhoff, R.D., Moore, R., Parrott, J.L., Snape, J.R., Murray-Smith, R., Servos, M.R., Sibley, P.K., Straub, J.O., Szabo, N.D., Topp, E., Tetreault, G.R., Trudeau, V.L. and Van Der Kraak, G. 2012. Pharmaceuticals and personal care products in the environment: What are the big questions? Environ. Health Persp. 120(9), 1221-1229.

Braga, O., Smythe, G.A., Schafer, A.I. and Feltz, A.J. 2005a. Fate of steroid estrogens in Australian inland and coastal wastewater treatment plants. Environ. Sci. Technol. 39, 3351-3358.

Braga, O., Smythe, G.A., Schafer, A.I. and Feltz, A.J. 2005b. Steroid estrogens in primary and tertiary wastewater treatment plants. Water Sci. Technol. 52(8), 273-278.

Brausch, J.M. and Rand, G.M. 2011. A review of personal care products in the aquatic environment: Environmental concentrations and toxicity. Chemosphere 82(11), 15181532.

Carlsson, C., Johansson, A.K., Alvan, G., Bergman, K. and Kuhler, T. 2006. Are pharmaceuticals potent environmental pollutants? Part I: Environmental risk assessments of selected active pharmaceutical ingredients. Sci. Total Environ. 364(1-3), $67-87$.

Chapman, H. 2003. Removal of endocrine disruptors by tertiary treatments and constructed wetlands in subtropical Australia. Water Sci. Technol. 47(9), 151-156.

Church, A., Wood, J., Kobayashi, T. and Doherty M. 2004. Pesticide discharges from irrigated agriculture in the Murray Irrigation Area, New South Wales, Australia. Australasian J. Ecotoxicol. 10: 21-32.

Coleman, H.M., Khan, S.J., Watkins, G. and Stuetz, R.M. 2008. Fate and analysis of endocrine disrupting chemicals in some sewage treatment plants in Australia. Water Sci. Technol. 58(11), 2187-2194. 
581 Crane, M., Maycock, D., Watts, C.D., Atkinson, C. and Johnson, I. 2007. Proposed EQS for 582 Water Framework Directive Annex VIII substances: linuron. Science Report $583 \quad$ HOEP670085/SR18, Bristol.

584 Davis, A., Lewis, S., Bainbridge, Z., Brodie, J. and Shannon E. 2008. Pesticide residues in 585 waterways of the Lower Burdekin Region: Challenges in ecotoxicological interpretation of monitoring data. Australasian J. Ecotoxicol. 14: 89-108.

Drury, B., J. Scott, E. Rosi-Marshall and J. Kelly. 2013. Triclosan exposure increases triclosan resistance and influences taxonomic composition of benthic bacterial communities. Environmental science \& technology 47: 8923-8930. doi:10.1021/es401919k.

Escher, B.I., Baumgartner, R., Koller, M., Treyer, K., Lienert, J. and McArdell, C.S. 2011. Environmental toxicology and risk assessment of pharmaceuticals from hospital wastewater. Water Res. 45(1), 75-92.

Fent, K., Weston, A.A. and Caminada, D. 2006. Ecotoxicology of human pharmaceuticals. Aquat. Toxicol. 76(2), 122-159.

Focazio, M.J., Kolpin, D.W., Barnes, K.K., Furlong, E.T., Meyer, M.T., Zaugg, S.D., Barber, L.B. and Thurman, M.E. 2008. A national reconnaissance for pharmaceuticals and other organic wastewater contaminants in the United States - II) Untreated drinking water sources. Sci. Total Environ. 402(2-3), 201-216.

Girling, A.E., Tattersfield, L., Mitchell, G.C., Crossland, N.O., Pascoe, D., Blockwell, S.J., Maund, S.J., Taylor, E.J., Wenzel, A., Janssen, C.R. and Juttner, I. 2000. Derivation of predicted no-effect concentrations for lindane, 3,4-dichloroaniline, atrazine, and copper. Ecotox. Environ. Safe. 46(2), 148-162.

Halden, R.U. and Paull, D.H. 2005. Co-occurrence of triclocarban and triclosan in US water resources. Environ. Sci. Technol. 39(6), 1420-1426. 
606 Halling-Sorensen, B., Lutzhoft, H.C.H., Andersen, H.R. and Ingerslev, F. 2000.

607 Environmental risk assessment of antibiotics: comparison of mecillinam, trimethoprim 608 and ciprofloxacin. J. Antimicrob. Chemoth. 46, 53-58.

609 Harada, A., Komori, K., Nakada, N., Kitamura, K. and Suzuki, Y. 2008. Biological effects of 610 PPCPs on aquatic lives and evaluation of river waters affected by different wastewater 611 treatment levels. Water Sci. Technol. 58(8), 1541-1546.

612 Henschel, K.P., Wenzel, A., Diedrich, M. and Fliedner, A. 1997. Environmental hazard 613 assessment of pharmaceuticals. Regul. Toxicol. Pharm. 25(3), 220-225.

614 Hummel, D., Loffler, D., Fink, G. and Ternes, T.A. 2006. Simultaneous determination of 615 psychoactive drugs and their metabolites in aqueous matrices by liquid chromatography 616 mass spectrometry. Environ. Sci. Technol. 40(23), 7321-7328.

617 Kasprzyk-Hordern, B., Dinsdale, R.M. and Guwy, A.J. 2008. The occurrence of

618 pharmaceuticals, personal care products, endocrine disruptors and illicit drugs in 619 surface water in South Wales, UK. Water Res. 42(13), 3498-3518.

620 Khan, S.J. and Ongerth, J.E. 2004. Modelling of pharmaceutical residues in Australian 621 sewage by quantities of use and fugacity calculations. Chemosphere 54(3), 355-367.

622 Kolpin, D.W., Barbash, J.E. and Gilliom, R.J. 1998. Occurrence of pesticides in shallow 623 groundwater of the United States: Initial results from the National Water-Quality $624 \quad$ Assessment Program. Environ. Sci. Technol. 32(5), 558-566.

625 Kolpin, D.W., Furlong, E.T., Meyer, M.T., Thurman, E.M., Zaugg, S.D., Barber, L.B. and 626 Buxton, H.T. 2002. Pharmaceuticals, hormones, and other organic wastewater 627 contaminants in U.S. streams, 1999-2000: a national reconnaissance. Environ. Sci. 628 Technol. 36(6), 1202-1211. 
629 Komori, K., Suzuki, Y., Minamiyama, M. and Harada, A. 2013. Occurrence of selected 630 pharmaceuticals in river water in Japan and assessment of their environmental risk. 631 Environ. Monit. Assess. 185(6), 4529-4536.

632 Krantz, M.J., Berger, J.S. and Hiatt, W.R. 2010. An aspirin a day: Are we barking up the 633 wrong willow tree? Pharmacotherapy 30(2), 115-118.

634 Leusch, F.D.L., Chapman, H.F., Kay, G.W., Gooneratne, S.R. and Tremblay, L.A. 2006.

635 Anal fin morphology and gonadal histopathology in mosquitofish (Gambusia 636 holbrooki) exposed to treated municipal sewage effluent. Arch. Environ. Con. Tox. 637 $50(4), 562-574$.

638

639

640 three to the Great Barrier Reef. Environ. Pollut. 157(8-9): 2470-2484.

Loos, R., Gawlik, B.M., Locoro, G., Rimaviciute, E., Contini, S. and Bidoglio, G. 2009. EUwide survey of polar organic persistent pollutants in European river waters. Environ. Pollut. 157(2), 561-568.

Loos, R., Locoro, G., Comero, S., Contini, S., Schwesig, D., Werres, F., Balsaa, P., Gans, O., 651

Metcalfe, C.D., Miao, X.S., Koenig, B.G. and Struger, J. 2003. Distribution of acidic and 652 neutral drugs in surface waters near sewage treatment plants in the lower Great Lakes, Canada. Environ. Toxicol. Chem. 22(12), 2881-2889. 
654 Mispagel, C., Allinson, G., Allinson, M., Shiraishi, F., Nishikawa, M. and Moore, M.R.

655 2009. Observations on the estrogenic activity and concentration of 17 beta-estradiol in 656 the discharges of 12 wastewater treatment plants in Southern Australia. Arch. Environ. 657 Con. Tox. 56(4), 631-637.

658 National Center for Biotechnology Information. 1999. Salicylic acid, USA Government, 659 Bethesda, USA.

660 Pedrouzo, M., Borrull, F., Marce, R.M. and Pocurull, E. 2009. Ultra-high-performance liquid 661 chromatography-tandem mass spectrometry for determining the presence of eleven 662 personal care products in surface and wastewaters. J. Chromatogr. A 1216(42), 6994$663 \quad 7000$.

664 Perez, A.L., De Sylor, M.A., Slocombe, A.J., Lew, M.G., Unice, K.M. and Donovan, E.P. 665 2013. Triclosan occurrence in freshwater systems in the United States (1999-2012): A 666 meta-analysis. Environ. Toxicol. Chem. 32(7), 1479-1487.

667 Pycke, B., G. Vanermen, P. Monsieurs, H. De Wever, M. Mergeay, W. Verstraete, et al. 668 2010. Toxicogenomic response of Rhodospirillum rubrum S1H to the micropollutant triclosan. Applied and environmental microbiology 76: 3503-3513. doi:10.1128/AEM.01254-09.

Quednow, K. and Puttmann, W. 2009. Temporal concentration changes of DEET, TCEP, terbutryn, and nonylphenols in freshwater streams of Hesse, Germany: possible influence of mandatory regulations and voluntary environmental agreements. Environ.

676 Sciences and Engineering, Victoria, Australia.

677 Regueiro, J., Becerril, E., Garcia-Jares, C. and Llompart, M. 2009. Trace analysis of 678 parabens, triclosan and related chlorophenols in water by headspace solid-phase 
679

680

681

682

683

684

685

686

687

688

689

690

691

692

693

694

695

696

697

698

699

700

701

702

microextraction with in situ derivatization and gas chromatography-tandem mass spectrometry. J. Chromatogr. A 1216(23), 4693-4702.

Sanchez-Bayo, F. and Hyne, R. 2014. Detection and analysis of neonicotinoids in river waters - Development of a passive sampler for three commonly used insecticides. Chemosphere 99: 143-151.

Santos, L., Araujo, A.N., Fachini, A., Pena, A., Delerue-Matos, C. and Montenegro, M. 2010. Ecotoxicological aspects related to the presence of pharmaceuticals in the aquatic environment. J. Hazard. Mater. 175(1-3), 45-95.

Schäfer, R.B., Pettigrove, V., Rose, G., Allinson, G., Wightwick, A., von der Ohe, P.C., Shimeta,. J., Kühne, R. and Kefford, B.J. 2011. Effects of pesticides monitored with three sampling methods in 24 sites on macroinvertebrates and microorganisms. Environ. Sci. Technol. 45: 1665-1672.

Schowanek, D. and Webb, S. 2002. Exposure simulation for pharmaceuticals in European surface waters with GREAT-ER. Toxicol. Lett. 131(1-2), 39-50.

Schwarzenbach, R.P., Escher, B.I., Fenner, K., Hofstetter, T.B., Johnson, C.A., von Gunten, U. and Wehrli, B. 2006. The challenge of micropollutants in aquatic systems. Science 313, 1072-1077.

Snyder, S., Wert, E., Lei, H.D., Westerhoff, P. and Yoon, Y. 2007. Removal of EDCs and pharmaceuticals in drinking and reuse treatment processes, American Water Works Research Foundation, Denver, USA.

Tamura, I., Kagota, K.-i., Yasuda, Y., Yoneda, S., Morita, J., Nakada, N., Kameda, Y., Kimura, K., Tatarazako, N. and Yamamoto, H. 2012. Ecotoxicity and screening level ecotoxicological risk assessment of five antimicrobial agents: triclosan, triclocarban, resorcinol, phenoxyethanol and p-thymol. J. Appl. Toxicol. doi: 10.1002/jat.2771.. 
703 Ternes, T.A. 1998. Occurrence of drugs in German sewage treatment plants and rivers. Water

$704 \quad$ Res. 32(11), 3245-3260.

705 Ternes, T.A., Stumpf, M., Mueller, J., Haberer, K., Wilken, R.D. and Servos, M. 1999.

706 Behavior and occurrence of estrogens in municipal sewage treatment plants - I.

707 Investigations in Germany, Canada and Brazil (vol 225, pg 81, 1999). Sci. Total

$708 \quad$ Environ. 228(1), 87-87.

709 U.S. Environmental Protection Agency. 2008. Screening-level hazard characterization of

710 high production volume chemicals, Washington, DC.

711 Vanderford, B.J. and Snyder, S.A. 2006. Analysis of pharmaceuticals in water by isotope

712 dilution liquid chromatography/tandem mass spectrometry. Environ. Sci. Technol.

$713 \quad 40(23), 7312-7320$.

714 Wang, L., Ying, G.G., Zhao, J.L., Yang, X.B., Chen, F., Tao, R., Liu, S. and Zhou, L.J. 2010.

715 Occurrence and risk assessment of acidic pharmaceuticals in the Yellow River, Hai

716 River and Liao River of north China. Sci. Total Environ. 408(16), 3139-3147.

717 Watkinson, A.J., Murby, E.J., Kolpin, D.W., Costanzo, S.D. 2009. The occurrence of

718 antibiotics in an urban watershed: From wastewater to drinking water. Sci. Total

$719 \quad$ Environ. 407: 2711-2723.

720 Williams, M., Woods, M., Kumar, A., Ying, G.G., Shareef, A., Karkkainen, M. and

721 Kookana, R. 2007. Endocrine disrupting chemicals in the Australian riverine

722 environment, Land and Water Australia / CSIRO, Braddon, ACT, Australia.

723 Winter, M.J., Lillicrap, A.D., Caunter, J.E., Schaffner, C., Alder, A.C., Ramil, M., Ternes,

724 T.A., Giltrow, E., Sumpter, J.P. and Hutchinson, T.H. 2008. Defining the chronic

725 impacts of atenolol on embryo-larval development and reproduction in the fathead

726 minnow (Pimephales promelas). Aquat. Toxicol. 86(3), 361-369. 
727 Yamamoto, H., Tamura, I., Hirata, Y., Kato, J., Kagota, K., Katsuki, S., Yamamoto, A.,

728 Kagami, Y. and Tatarazako, N. 2011. Aquatic toxicity and ecological risk assessment

729 of seven parabens: Individual and additive approach. Sci. Total Environ. 410, 102-111.

730 Ying, G.-G., Kookana, R.S., Kolpin, D.W. 2009. Occurrence and removal of

731 pharmaceutically active compounds in sewage treatment plants with different

732 technologies. J. Environ. Monit. 11: 1498-1505. 


\section{Figure titles -}

734 Figure 1 - Location of sampling sites across mainland Australia. State and territory capitals 735 are depicted by white stars, while black circles represent sampling locations. The population 736 density graph was obtained from the Australian Bureau of Statistics (2012).

738 Figure 2. (top) Frequency of detection for the five most detected compounds for each land-

739 use. Salicylic acid and caffeine were the most and second most commonly detected

740 compounds in each land-use. (bottom) Frequency of detection for the five most detected

741 compounds in each state. Salicylic acid and caffeine were again the first and second most

742 detected compounds, respectively, in all six states and territories. Numbers in brackets

743 represent the total number of samples analyzed for the respective compound. "TCEP" =

744 tris(2-Chloroethyl) phosphate. 
745 Tables -

746

747 Table 1. The number of samples collected during the four separate sampling events

748 and the dominant land-use at each site. WWTP = wastewater treatment plant.

749

\begin{tabular}{lcccc}
\hline $\begin{array}{l}\text { Dominant adjoining } \\
\text { land-use }\end{array}$ & $\begin{array}{c}\text { Autumn } \\
\text { May-11 }\end{array}$ & $\begin{array}{c}\text { Winter } \\
\text { Aug-11 }\end{array}$ & $\begin{array}{c}\text { Spring } \\
\text { Nov-11 }\end{array}$ & $\begin{array}{c}\text { Summer } \\
\text { Feb-12 }\end{array}$ \\
\hline Agricultural & 20 & 20 & 20 & 20 \\
Industrial & 7 & 7 & 7 & 7 \\
Residential & 19 & 19 & 18 & 18 \\
WWTP & 13 & 13 & 12 & 12 \\
Undeveloped & 14 & 14 & 12 & 13 \\
\hline Total & $\mathbf{7 3}$ & $\mathbf{7 3}$ & $\mathbf{6 9}$ & $\mathbf{7 0}$ \\
\hline
\end{tabular}


Table 2. Chemical limit of quantification (LOQ) and number of detections above the LOQ throughout four sampling events during a one-year period for targeted trace organic pollutants (TrOCs). "CASRN" = Chemical Abstracts Service Registry Number; "NA" = not analyzed; "NR" = not reported (DEET only).

\begin{tabular}{|c|c|c|c|c|c|c|c|}
\hline \multirow[b]{2}{*}{ Contaminant } & \multirow[b]{2}{*}{ CASRN } & \multirow[b]{2}{*}{ Use } & \multirow[b]{2}{*}{$\begin{array}{c}\text { LOQ } \\
(\mathrm{ng} / \mathrm{L})\end{array}$} & \multicolumn{4}{|c|}{ Detection Frequency (\%) } \\
\hline & & & & $\begin{array}{c}\text { Autumn } \\
\text { May-11 } \\
\mathrm{n}=73\end{array}$ & $\begin{array}{c}\text { Winter } \\
\text { Aug-11 } \\
\mathbf{n}=73\end{array}$ & $\begin{array}{c}\text { Spring } \\
\text { Nov-11 } \\
\mathrm{n}=69 \\
\end{array}$ & $\begin{array}{c}\text { Summer } \\
\text { Feb-12 } \\
\mathrm{n}=70 \\
\end{array}$ \\
\hline tris(2-Chloroethyl) phosphate (TCEP) & $115-96-8$ & flame retardant & 10 & 33 & 42 & 45 & 56 \\
\hline \multicolumn{8}{|l|}{ Pharmaceuticals } \\
\hline Amitriptyline & $50-48-6$ & antidepressant & 10 & 0 & 3 & 3 & 0 \\
\hline o-Hydroxy atorvastatin & $265989-46-6$ & atorvastatin metabolite & 5 & 7 & NA & NA & NA \\
\hline p-Hydroxy atorvastatin & $214217-86-6$ & atorvastatin metabolite & 5 & 5 & NA & NA & NA \\
\hline Carbamazepine & $298-46-4$ & anticonvulsant & 5 & 25 & 33 & 25 & 27 \\
\hline Clozapine & $5786-21-0$ & antipsychotic & 5 & 3 & 7 & 1 & 3 \\
\hline Diazepam & $439-14-5$ & benzodiazepine tranquilizer & 5 & 0 & 1 & 0 & 1 \\
\hline Ibuprofen & $15687-27-1$ & anti-inflammatory & 5 & 7 & 5 & 3 & 3 \\
\hline Ketoprofen & $22071-15-4$ & anti-inflammatory & 10 & 0 & 0 & 0 & 0 \\
\hline Meprobamate & $57-53-4$ & anti-anxiety agent & 10 & 0 & NA & 0 & 0 \\
\hline
\end{tabular}




\begin{tabular}{|c|c|c|c|c|c|c|c|}
\hline Methotrexate & 21672 & antifolate & 50 & NA & NA & 0 & NA \\
\hline Naproxen & $22204-53-1$ & anti-inflammatory & 5 & 4 & 4 & 4 & 1 \\
\hline Paracetamol & $103-90-2$ & antipyretic & 5 & 38 & 47 & NA & 50 \\
\hline Primidone & $125-33-7$ & anticonvulsant & 5 & 22 & 8 & 16 & 10 \\
\hline Risperidone & $106266-06-2$ & antipsychotic & 5 & 0 & 0 & 0 & 0 \\
\hline Salicylic acid & $69-72-7$ & antiacne, acetylsalicylic acid metabolite & 20 & 78 & 64 & 100 & 86 \\
\hline Sulfamethoxazole & $723-46-6$ & antibiotic & 5 & 11 & 10 & 10 & 4 \\
\hline Triamterene & $396-01-0$ & for hypertension and edema & 5 & 0 & 1 & 3 & 0 \\
\hline Trimethoprim & $738-70-5$ & antibiotic & 5 & 5 & 7 & 4 & 3 \\
\hline Verapamil & $52-53-9$ & antiarrhythmic & 5 & 0 & 1 & 1 & 0 \\
\hline \multicolumn{8}{|l|}{ Personal care products } \\
\hline Triclosan & $3380-34-5$ & antibacterial & 10 & 33 & 19 & 22 & 26 \\
\hline \multicolumn{8}{|l|}{ Pesticides } \\
\hline Atrazine & $1912-24-9$ & herbicide & 5 & 5 & 16 & 9 & 13 \\
\hline Chlorpyrifos & $2921-88-2$ & insecticide & 5 & NA & NA & 3 & NA \\
\hline Diazinon & $333-41-5$ & insecticide & 5 & NA & NA & 0 & NA \\
\hline Linuron & $330-55-2$ & herbicide & 5 & 1 & 4 & 4 & 3 \\
\hline 2-Phenylphenol & $90-43-7$ & biocide & 10 & 3 & 3 & 10 & 39 \\
\hline Simazine & $122-34-9$ & herbicide & 5 & $\mathrm{NA}$ & NA & 10 & 17 \\
\hline
\end{tabular}


Trifluralin

1582-09-8

herbicide

150

NA

NA

0

NA

754 *Not reported, see section 3.1.5 for more information. 


\begin{tabular}{|c|c|c|c|c|c|c|c|c|}
\hline Compound & $\begin{array}{c}\text { \# samples } \\
\text { analyzed } \\
\text { (n) }\end{array}$ & $\begin{array}{c}\text { Detection } \\
\text { frequency } \\
(\%)\end{array}$ & $\begin{array}{c}\text { Mean } \pm \text { SE } \\
(\text { ng/L) }\end{array}$ & $\begin{array}{c}\mathbf{5 0}^{\text {th }} \\
\text { percentile } \\
(\mathrm{ng} / \mathrm{L})\end{array}$ & $\begin{array}{c}\mathbf{9 5}^{\text {th }} \\
\text { percentile } \\
\text { (ng/L) }\end{array}$ & $\begin{array}{c}\text { Maximum } \\
\text { value } \\
\text { (ng/L) }\end{array}$ & $\begin{array}{c}\text { Predicted No } \\
\text { Effect } \\
\text { Concentrations } \\
\text { (PNEC)* } \\
\text { (ng/L) }\end{array}$ & $\begin{array}{c}\text { Hazard } \\
\text { Quotient } \\
\text { (Max/PNEC) }\end{array}$ \\
\hline \multicolumn{9}{|l|}{ Industrial compound } \\
\hline tris(2-Chloroethyl) phosphate (TCEP) & 285 & $44 \%$ & $19 \pm 2$ & $<10$ & 89 & 184 & $65,000^{\text {a }}$ & 0.0028 \\
\hline \multicolumn{9}{|l|}{ Pharmaceuticals } \\
\hline Atorvastatin & 73 & 0 & $<5$ & $<5$ & $<5$ & $<5$ & $24,000^{\mathrm{b}}$ & $<0.00021$ \\
\hline o-Hydroxy atorvastatin & 73 & $7 \%$ & $<5$ & $<5$ & 7 & 20 & NA & NA \\
\hline p-Hydroxy atorvastatin & 73 & $5 \%$ & $<5$ & $<5$ & 7 & 34 & NA & NA \\
\hline Carbamazepine & 285 & $27 \%$ & $30 \pm 6$ & $<5$ & 171 & 682 & $500^{b}$ & 1.4 \\
\hline Clozapine & 285 & $4 \%$ & $<5$ & $<5$ & $<5$ & 90 & $16,000^{\mathrm{d}}$ & 0.0056 \\
\hline Diazepam & 285 & $1 \%$ & $<5$ & $<5$ & $<5$ & 8 & $4,300^{\mathrm{e}}$ & 0.0019 \\
\hline Ibuprofen & 285 & $5 \%$ & $<5$ & $<5$ & $<5$ & 44 & $1,650^{\mathrm{b}}$ & 0.027 \\
\hline Ketoprofen & 285 & 0 & $<10$ & $<10$ & $<10$ & $<10$ & $2,000^{\mathrm{h}}$ & $<0.005$ \\
\hline Meprobamate & 212 & 0 & $<10$ & $<10$ & $<10$ & $<10$ & NA & NA \\
\hline
\end{tabular}




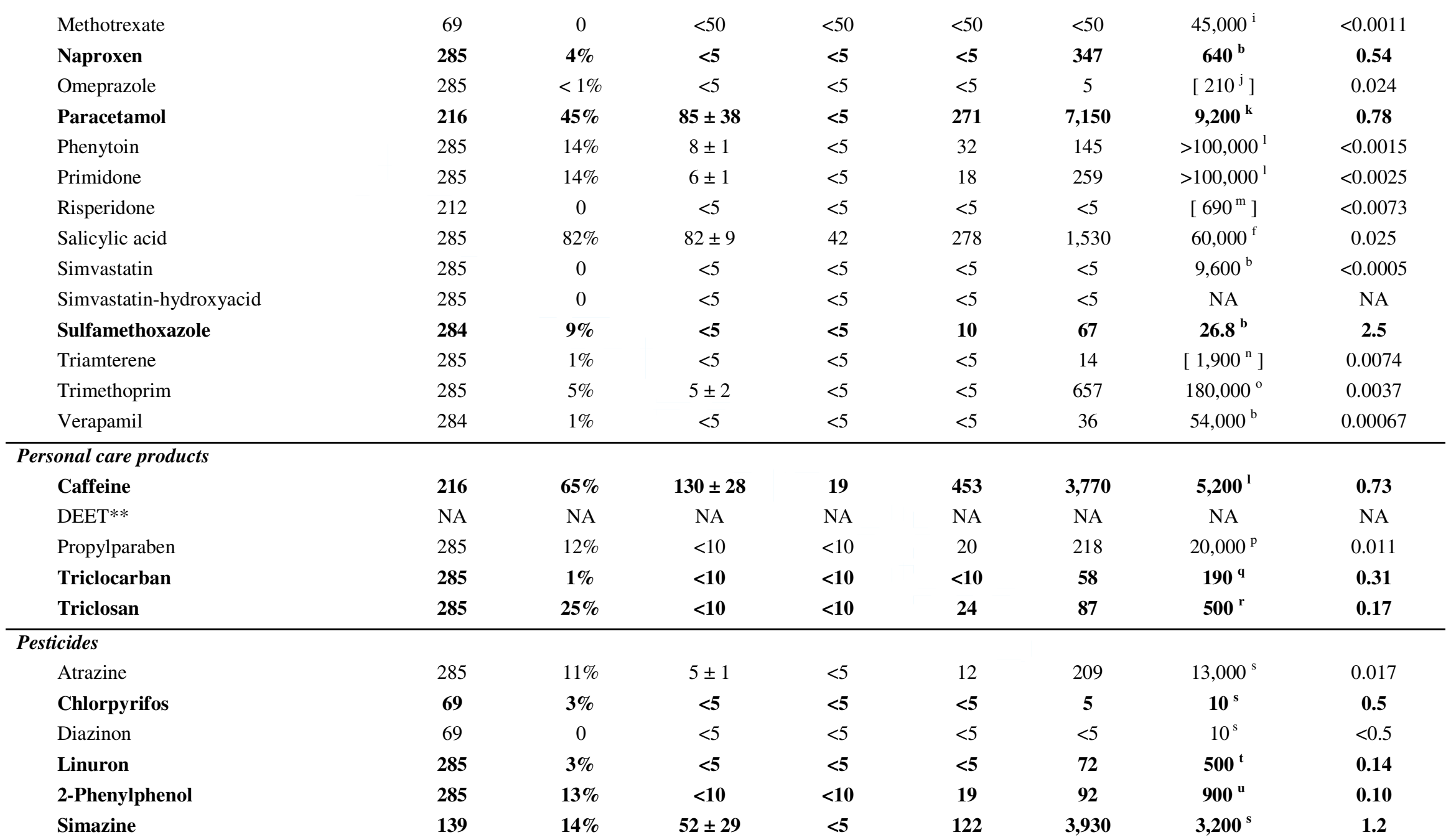


${ }^{\mathrm{a}}$ Quednow and Puttmann $2009{ }^{\mathrm{b}}$ Agerstrand and Ruden $2010{ }^{\mathrm{c}}$ Derived based on no observable effect concentration (NOEC) for condition index in fathead minnow of $1 \mathrm{mg} / \mathrm{L}$, as reported in Winter et al. (2008) with an uncertainty factor (UF) of $100{ }^{\mathrm{d}}$ Escher et al. $2011{ }^{\mathrm{e}} \mathrm{Carlsson}$ et al. $2006{ }^{\mathrm{f}} \mathrm{Wang}$ et al. 2010 ${ }^{\mathrm{g}}$ Derived based on $\mathrm{EC}_{50}$ for green algae $(96 \mathrm{~h})$ of $3.9 \mathrm{mg} / \mathrm{L}$, as calculated by ECOSAR, with a UF of $1000{ }^{\mathrm{h}}$ Derived based on EC ${ }_{50}$ for growh inhibition of $P$. subcapitata of $2 \mathrm{mg} / \mathrm{L}$, as reported in Harada et al. 2008, with a UF of $1000{ }^{\mathrm{i}}$ Derived based on EC $\mathrm{E}_{50}$ for growth inhibition of $T$. pyriformis of $45 \mathrm{mg} / \mathrm{L}$, as reported in Henschel et al. 1997, with a UF of $1000{ }^{\mathrm{j} D e r i v e d ~ b a s e d ~ o n ~} \mathrm{EC}_{50}$ for green algae (96h) of $0.21 \mathrm{mg} / \mathrm{L}$, as calculated by ECOSAR, with a UF of 1000 ${ }^{\mathrm{k}}$ Schowanek and Webb $2002{ }^{\mathrm{l}}$ Komori et al. $2013{ }^{\mathrm{m}}$ Derived based on EC $\mathrm{E}_{50}$ for green algae (96h) of 0.69 mg/L, as calculated by ECOSAR, with a UF of 1000 ${ }^{\mathrm{n}}$ Derived based on $\mathrm{LC}_{50}$ for daphnid (48h) of $1.9 \mathrm{mg} / \mathrm{L}$, as calculated by ECOSAR, with a UF of $1000{ }^{\circ} \mathrm{Halling}$-Sorensen et al. $2000{ }^{\mathrm{p}}$ Yamamoto et al. 2011 ${ }^{\mathrm{q}}$ Derived from a NOEC based on an $8 \mathrm{~d}$ chronic toxicity test with $C$. dubia reported in Tamura et al. (2012), with a UF of $10{ }^{\mathrm{r}}$ Perez et al. 2013 ${ }^{\mathrm{s}}$ ANZECC/ARMCANZ $200095^{\text {th }}$ percentile ${ }^{\text {t}}$ Crane et al. 2007 u Derived from a NOEC based on a D. magna reproduction test in Bayer 2001 , with a UF of 10 $768{ }^{\mathrm{v}}$ ANZECC/ARMCANZ 2000, $99^{\text {th }}$ percentile 


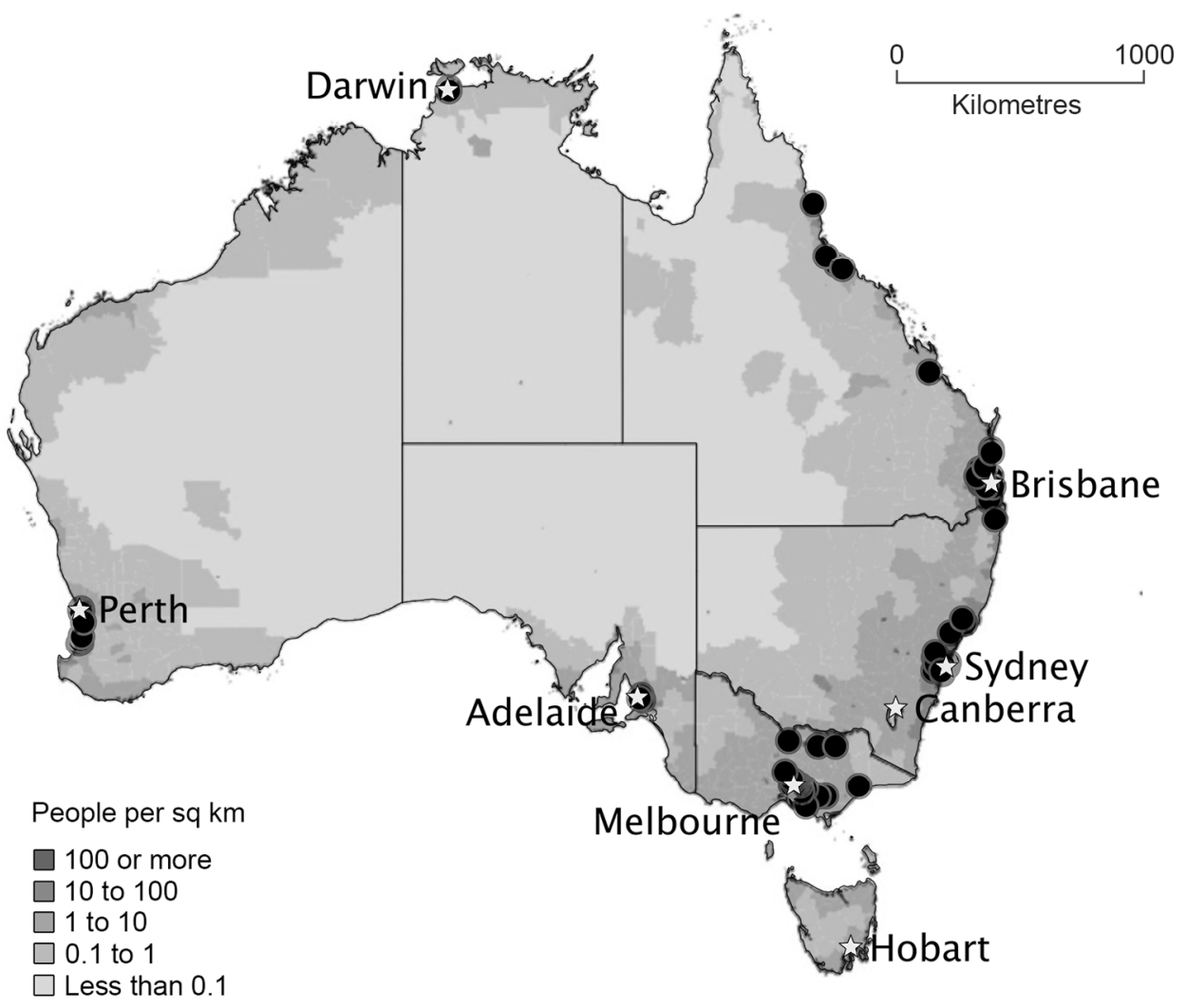

Figure 1 - Location of sampling sites across mainland Australia. State and territory capitals are depicted by white stars, while black circles represent sampling locations. The population density graph was obtained from the Australian Bureau of Statistics (2012).

$285 \times 240 \mathrm{~mm}(150 \times 150 \mathrm{DPI})$ 


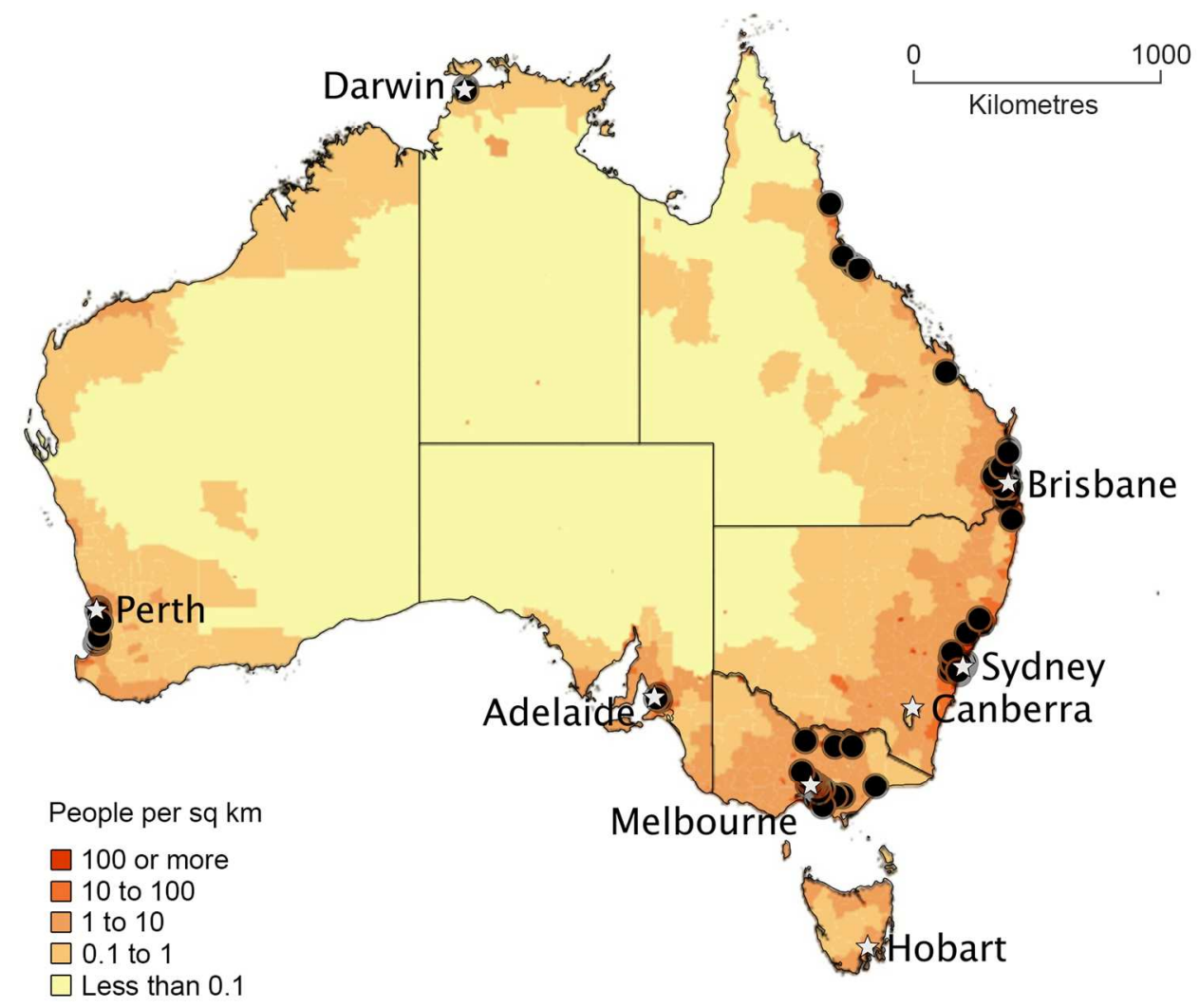

Figure 1 - Location of sampling sites across mainland Australia. State and territory capitals are depicted by white stars, while black circles represent sampling locations. The population density graph was obtained from the Australian Bureau of Statistics (2012).

$285 \times 240 \mathrm{~mm}(150 \times 150 \mathrm{DPI})$ 

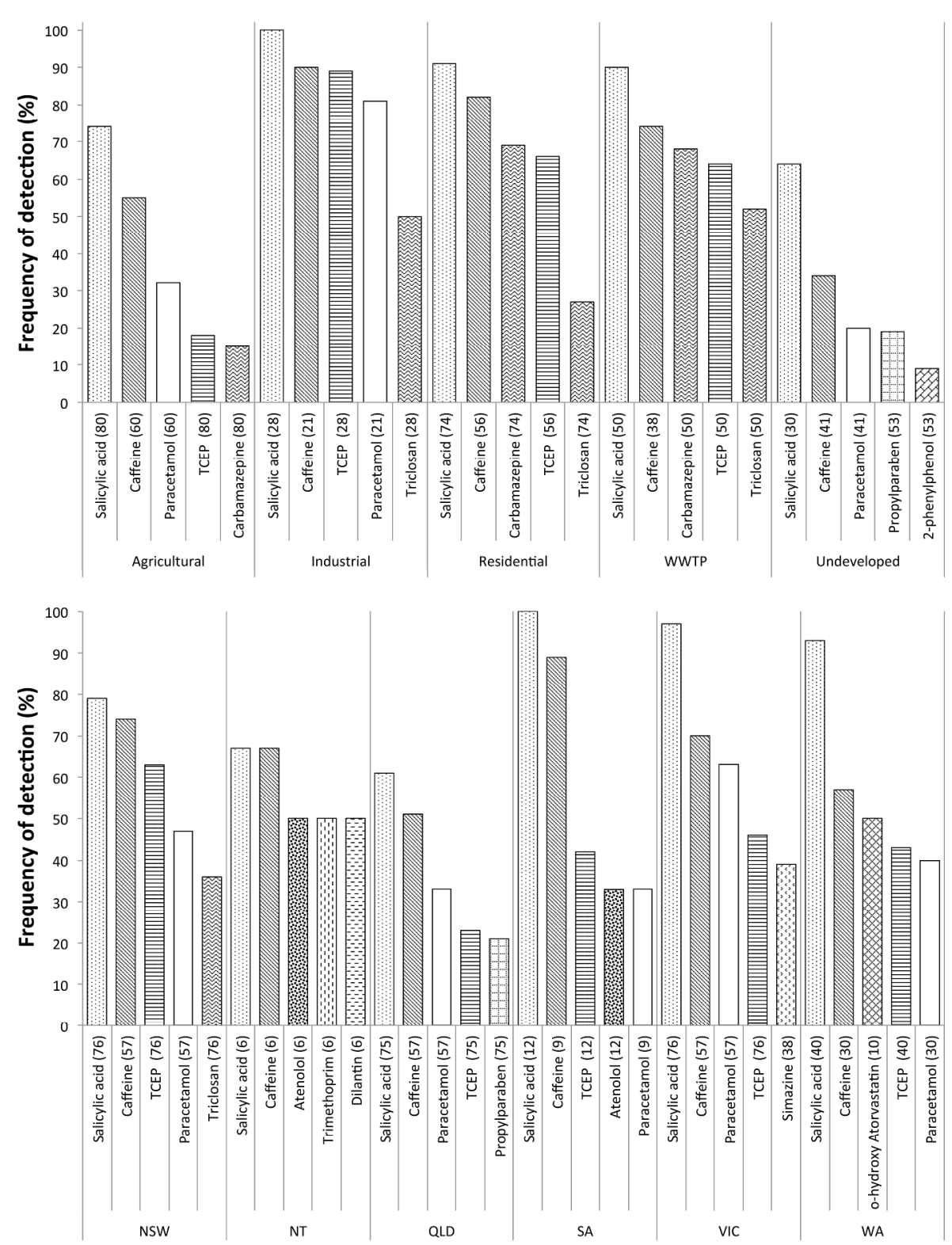

Figure 2. (top) Frequency of detection for the five most detected compounds for each land-use. Salicylic acid and caffeine were the most and second most commonly detected compounds in each land-use. (bottom) Frequency of detection for the five most detected compounds in each state. Salicylic acid and caffeine were again the first and second most detected compounds, respectively, in all six states and territories. Numbers in brackets represent the total number of samples analysed for the respective compound. "TCEP" $=\operatorname{tris}(2-$ Chloroethyl) phosphate. $255 \times 327 \mathrm{~mm}(300 \times 300 \mathrm{DPI})$ 


\section{SUPPLEMENTARY INFORMATION FOR}

\section{A national survey of trace organic contaminants in Australian}

\section{rivers}

Philip D. Scott ${ }^{\mathrm{a}}$, Michael Bartkow ${ }^{\mathrm{b}}$, Stephen J. Blockwell ${ }^{\mathrm{c}}$, Heather M. Coleman ${ }^{\mathrm{d}}$, Stuart J. Khan ${ }^{\mathrm{d}}$, Richard Lim ${ }^{\mathrm{e}}$, James A. McDonald ${ }^{\mathrm{d}}$, Helen Nice ${ }^{\mathrm{f}}$, Dayanthi Nugegoda ${ }^{\mathrm{g}}$, Vincent Pettigrove ${ }^{\mathrm{h}}$, Louis A. Tremblay ${ }^{\mathrm{i}, \mathrm{j}}$, Michael St. J. Warne ${ }^{\mathrm{k}}$, and Frederic D.L. Leusch ${ }^{\mathrm{a}, *}$

${ }^{a}$ School of Environment, Griffith University, Southport, Queensland, 4222, Australia

${ }^{\mathrm{b}}$ Seqwater, PO Box 16146, Brisbane City East, Queensland, 4002, Australia

c Sydney Water Corporation, PO Box 399, Parramatta, New South Wales, 2124, Australia

${ }^{\mathrm{d}}$ School of Civil \& Environmental Engineering, University of New South Wales, New South Wales, 2052, Australia

${ }^{\mathrm{e}}$ School of the Environment, University of Technology Sydney, PO Box 123, Broadway, New South Wales, 2007, Australia

${ }^{\mathrm{f}}$ Water Science Branch, Department of Water, Government of Western Australia, PO Box K822, Perth, Western Australia, 6842, Australia

${ }^{g}$ School of Applied Sciences, Royal Melbourne Institute of Technology, PO Box 71, Bundoora, Victoria, 3083, Australia

${ }^{\text {h }}$ Melbourne Water, PO Box 4342, Melbourne, Victoria, 3001, Australia

${ }^{i}$ Cawthron Institute, 98 Halifax Street East, Nelson, 7042, New Zealand

${ }^{j}$ School of Biological Sciences, University of Auckland, PO Box 92019, Auckland, 1142, New

Zealand

${ }^{\mathrm{k}}$ Water Quality and Investigations, Department of Science, Information, Technology, Innovation and the Arts, Queensland Government, GPO Box 5078, Brisbane, Queensland, 4001, Australia

* Corresponding Author.

e: f.leusch@griffith.edu.au 
p: +61755527832

Mailing address:

Dr Frederic Leusch

Smart Water Research Centre (G51)

Griffith University, Gold Coast Campus

Southport, Queensland, 4222

Australia 
Table S1. Catchment composition based on primary land-use. Catchment assessments were performed for each sampling site to assess the impact of agricultural, industrial, residential, wastewater treatment plant (WWTP) effluent, and undeveloped inputs at each sampling location. The dominant land-use was used for grouping.

\begin{tabular}{|c|c|c|c|c|c|}
\hline \multirow[b]{2}{*}{ Site } & \multicolumn{5}{|c|}{ Catchment composition (percent total catchment) } \\
\hline & Agricultural & Industrial & Residential & WWTP & Undeveloped \\
\hline \multicolumn{6}{|c|}{ Agricultural sites $(n=20)$} \\
\hline 1 & 40 & 0 & 20 & 30 & 10 \\
\hline 2 & 70 & 10 & 10 & 10 & 0 \\
\hline 3 & 50 & 0 & 10 & 20 & 20 \\
\hline 4 & 60 & 0 & 0 & 0 & 40 \\
\hline 5 & 95 & 0 & 0 & 0 & 5 \\
\hline 6 & 90 & 0 & 10 & 0 & 0 \\
\hline 7 & 90 & 0 & 10 & 0 & 0 \\
\hline 8 & 80 & 20 & 0 & 0 & 0 \\
\hline 9 & 80 & 10 & 10 & 0 & 0 \\
\hline 10 & 80 & 0 & 10 & 0 & 10 \\
\hline 11 & 100 & 0 & 0 & 0 & 0 \\
\hline 12 & 100 & 0 & 0 & 0 & 0 \\
\hline 13 & 90 & 0 & 0 & 0 & 10 \\
\hline 14 & 80 & 0 & 20 & 0 & 0 \\
\hline 15 & 70 & 0 & 30 & 0 & 0 \\
\hline 16 & 100 & 0 & 0 & 0 & 0 \\
\hline 17 & 75 & 0 & 5 & 0 & 20 \\
\hline 18 & 70 & 0 & 30 & 0 & 0 \\
\hline 19 & 100 & 0 & 0 & 0 & 0 \\
\hline 20 & 60 & 0 & 0 & 0 & 40 \\
\hline \multicolumn{6}{|c|}{ Industrial sites $(n=7)$} \\
\hline 21 & 0 & 60 & 40 & 0 & 0 \\
\hline 22 & 0 & 80 & 20 & 0 & 0 \\
\hline 23 & 0 & 80 & 20 & 0 & 0 \\
\hline 24 & 0 & 80 & 20 & 0 & 0 \\
\hline 25 & 0 & 100 & 0 & 0 & 0 \\
\hline 26 & 0 & 100 & 0 & 0 & 0 \\
\hline 27 & 0 & 90 & 10 & 0 & 0 \\
\hline \multicolumn{6}{|c|}{ Residential sites $(n=19)$} \\
\hline 28 & 0 & 20 & 80 & 0 & 0 \\
\hline 29 & 0 & 20 & 60 & 20 & 0 \\
\hline 30 & 0 & 0 & 90 & 0 & 10 \\
\hline 31 & 0 & 0 & 100 & 0 & 0 \\
\hline 32 & 0 & 0 & 50 & 0 & 50 \\
\hline 33 & 0 & 5 & 65 & 0 & 30 \\
\hline 34 & 0 & 0 & 60 & 0 & 40 \\
\hline 35 & 0 & 20 & 80 & 0 & 0 \\
\hline 36 & 0 & 10 & 90 & 0 & 0 \\
\hline
\end{tabular}




\begin{tabular}{|c|c|c|c|c|c|}
\hline & & & & & \\
\hline 37 & 0 & 30 & 70 & 0 & 0 \\
\hline 38 & 0 & 20 & 80 & 0 & 0 \\
\hline 39 & 0 & 20 & 80 & 0 & 0 \\
\hline 40 & 0 & 0 & 100 & 0 & 0 \\
\hline 41 & 0 & 0 & 100 & 0 & 0 \\
\hline 42 & 20 & 0 & 60 & 0 & 20 \\
\hline 43 & 0 & 20 & 80 & 0 & 0 \\
\hline 44 & 0 & 0 & 80 & 0 & 20 \\
\hline 45 & 0 & 20 & 80 & 0 & 0 \\
\hline 46 & 0 & 0 & 80 & 0 & 20 \\
\hline \multicolumn{6}{|c|}{ WWTP sites $(n=13)$} \\
\hline 47 & 0 & 0 & 0 & 60 & 40 \\
\hline 48 & 15 & 5 & 30 & 50 & 0 \\
\hline 49 & 5 & 15 & 40 & 40 & 0 \\
\hline 50 & 0 & 10 & 40 & 50 & 0 \\
\hline 51 & 0 & 20 & 20 & 60 & 0 \\
\hline 52 & 20 & 0 & 0 & 60 & 20 \\
\hline 53 & 0 & 0 & 0 & 100 & 0 \\
\hline 54 & 20 & 0 & 20 & 50 & 10 \\
\hline 55 & 20 & 0 & 0 & 60 & 20 \\
\hline 56 & 30 & 0 & 0 & 70 & 0 \\
\hline 57 & 20 & 0 & 0 & 80 & 0 \\
\hline 58 & 0 & 0 & 0 & 80 & 20 \\
\hline 59 & 30 & 0 & 0 & 60 & 10 \\
\hline \multicolumn{6}{|c|}{ Undeveloped sites $(n=14)$} \\
\hline 60 & 0 & 0 & 10 & 0 & 90 \\
\hline 61 & 10 & 0 & 10 & 0 & 80 \\
\hline 62 & 20 & 0 & 0 & 0 & 80 \\
\hline 63 & 0 & 0 & 10 & 0 & 90 \\
\hline 64 & 20 & 0 & 10 & 0 & 70 \\
\hline 65 & 0 & 0 & 0 & 0 & 100 \\
\hline 66 & 0 & 0 & 0 & 0 & 100 \\
\hline 67 & 0 & 0 & 10 & 0 & 90 \\
\hline 68 & 30 & 0 & 0 & 30 & 40 \\
\hline 69 & 40 & 0 & 0 & 0 & 60 \\
\hline 70 & 0 & 0 & 0 & 0 & 100 \\
\hline 71 & 0 & 0 & 0 & 0 & 100 \\
\hline 72 & 0 & 10 & 0 & 0 & 90 \\
\hline 73 & 0 & 0 & 10 & 0 & 90 \\
\hline
\end{tabular}


Table S2. Basic water parameters and meteorological data. Ranges reported here are based on four sampling events. $\mathrm{pH}$, water temperature, dissolved oxygen (DO) and electro-conductivity (EC) determined via multi-meter. Nitrate, nitrite, total chlorine, free chlorine, total hardness, total alkalinity, $\mathrm{pH}$ (Hach strip) all determined using Hach strips (Section 2.3). Average atmospheric temperature and total precipitation values calculated for the week prior to sampling day (data downloaded for the nearest weather station from the Australian Bureau of Meteorology). "NA" = not available.

\begin{tabular}{|c|c|c|c|c|c|c|c|c|c|c|c|c|c|}
\hline $\begin{array}{r}\text { Site } \\
\text { Number }\end{array}$ & $\mathrm{pH}$ & $\begin{array}{c}\text { Water } \\
\text { temperature } \\
\text { (oC) } \\
\end{array}$ & $\begin{array}{c}\begin{array}{c}\text { Dissolved } \\
\text { oxygen } \\
\text { (mg/L) }\end{array} \\
\end{array}$ & $\begin{array}{c}\text { Electro- } \\
\text { conductivity } \\
\left(\mu \mathrm{S} / \mathrm{cm}^{2}\right)\end{array}$ & $\begin{array}{l}\text { Nitrate } \\
(\mathrm{ppm})\end{array}$ & $\begin{array}{l}\text { Nitrite } \\
(\mathrm{ppm})\end{array}$ & $\begin{array}{c}\text { Total chlorine } \\
(\mathrm{ppm})\end{array}$ & $\begin{array}{c}\text { Free } \\
\text { chlorine } \\
(\mathrm{ppm}) \\
\end{array}$ & $\begin{array}{c}\text { Total } \\
\text { hardness } \\
\left(\text { ppm; } \mathrm{CaCO}_{3}\right)\end{array}$ & $\begin{array}{c}\text { Total } \\
\text { alkalinity } \\
\left(\text { (ppm; } \mathrm{CaCO}_{3}\right)\end{array}$ & $\begin{array}{c}\mathrm{pH} \\
\text { (Hach } \\
\text { strip) } \\
\end{array}$ & $\begin{array}{c}\text { Atmospheric } \\
\text { temperature } \\
\text { (oC) }\end{array}$ & $\begin{array}{c}\text { Precipitation } \\
(\mathrm{mm})\end{array}$ \\
\hline \multicolumn{14}{|c|}{ New South Wales } \\
\hline 1 & $7.1-7.9$ & $14-25$ & $8.2-10.1$ & $182-243$ & $0.15-0.5$ & $0-1$ & $0-0.01$ & 0 & $50-120$ & $40-80$ & $6.8-7.2$ & $9.8-21.7$ & $1.4-66.4$ \\
\hline 2 & $7-7.8$ & $15-26$ & $7.7-810.5$ & $185-277$ & $0-0.5$ & $0-0.5$ & $0-0.06$ & 0 & $50-50$ & $40-80$ & $6.8-7.2$ & $10.3-22.1$ & $0.4-46.2$ \\
\hline 3 & $7.3-7.7$ & $13.4-26.2$ & $6.1-8.9$ & $643-1421$ & $0.15-1$ & $0-1.5$ & 0 & 0 & $7-120$ & $80-120$ & $7.2-7.6$ & $10.3-22.1$ & $0.4-46.2$ \\
\hline 4 & $7.2-8$ & $13.9-23.2$ & $6.3-8.5$ & $185-1078$ & $0-0.5$ & $0.15-1.5$ & 0 & 0 & $7-250$ & $50-180$ & $7.2-7.8$ & $11.7-23.2$ & $5.8-44.1$ \\
\hline 5 & $5.2-7.8$ & $17.7-26.3$ & $6.2-9.5$ & $0-1262$ & $0.15-2$ & $0-1$ & 0 & 0 & $50-120$ & $40-120$ & $6.8-7.2$ & $14.5-21.5$ & $1.2-72.4$ \\
\hline 6 & $7.1-8$ & $22.4-24.1$ & $4.3-8.3$ & $200-325$ & $0.15-0.5$ & $0-1$ & 0 & 0 & $50-50$ & $40-80$ & $6.8-7.8$ & $9.2-23.6$ & $2.6-82.2$ \\
\hline 7 & $6.9-7.8$ & $15.4-22$ & $4.5-9.3$ & $63-4686$ & $0-1$ & $0-1$ & 0 & 0 & $25-425$ & $60-120$ & $6.8-7.8$ & $11.2-22.6$ & $7.8-40.8$ \\
\hline 8 & $7.3-7.5$ & $10.2-20.7$ & $5.4-90$ & $230-397$ & $0-2$ & $0-0.15$ & 0 & 0 & $120-120$ & $60-80$ & $6.8-7.2$ & $12-23.2$ & $2-71$ \\
\hline 9 & $7.2-7.6$ & $12.2-24.4$ & $6.3-10.4$ & $89-224$ & $0.15-2$ & $0-0.15$ & 0 & 0 & $50-50$ & $40-120$ & $6.8-7.2$ & $14.3-22.9$ & $10.6-120.2$ \\
\hline 10 & $6.2-7.6$ & $17-25.5$ & $3.4-6.6$ & $9-41$ & $0.15-2$ & $0-1$ & 0 & 0 & $25-425$ & $180-240$ & $7.2-7.8$ & $12.9-22.2$ & $1.2-58.8$ \\
\hline 11 & $7.3-8.7$ & $15-24$ & $1.9-19.2$ & $9-1055$ & $0-2$ & $0-1$ & 0 & 0 & $25-425$ & $120-240$ & $7.2-8.4$ & $11.7-20.8$ & $8-63$ \\
\hline 12 & $6.9-7.9$ & $17-25.2$ & $1.9-8.3$ & $16-47$ & $0-2$ & $0-0.15$ & 0 & 0 & $25-425$ & $120-240$ & $6.8-7.8$ & $12.9-22.2$ & $1.2-58.8$ \\
\hline 13 & $7.1-7.7$ & $12.5-21.2$ & $2.3-8.7$ & $102-977$ & $0-1.5$ & $0.15-0.65$ & 0 & 0 & $50-250$ & $120-240$ & $6.8-7.6$ & $20.6-21.1$ & $67.4-74.4$ \\
\hline 14 & $7.2-7.5$ & $11-22.7$ & $1.6-6.6$ & $685-1414$ & $0-0.5$ & $0.05-1$ & 0 & 0 & $10-120$ & $120-180$ & $6.8-7.8$ & $11.1-23.2$ & $2.4-39.6$ \\
\hline 15 & $6.8-7.6$ & $12.4-22$ & $4.2-8.8$ & $307-1038$ & $0.15-3.5$ & $0-0.5$ & 0 & 0 & $120-250$ & $40-240$ & $7-7.8$ & $11.1-21.8$ & $6.4-60.4$ \\
\hline 16 & $7.1-8$ & $10.8-22.5$ & 7.1 - 10.8 & $60-148$ & $0.15-1.5$ & $0-1$ & 0 & 0 & $25-50$ & $20-100$ & $6.8-7.2$ & $12-20.3$ & $41.4-109.4$ \\
\hline 17 & $6.9-7.6$ & $11.1-26.8$ & $8-10.4$ & $75-121$ & $0-1.5$ & $0-0.5$ & 0 & 0 & $25-50$ & $20-40$ & $6.8-7.2$ & $10.9-23.7$ & $0.6-51.6$ \\
\hline 18 & $5-6$ & $10.1-18$ & $9.1-10.7$ & $138-172$ & $0.15-1$ & $0-0.5$ & 0 & 0 & $25-50$ & $20-40$ & $6.2-7$ & $11.1-20.6$ & $0-83.6$ \\
\hline 19 & $6.4-7.7$ & $11.3-20.9$ & $9.1-10.9$ & $109-171$ & $0-0.15$ & $0-1$ & 0 & 0 & $25-85$ & $40-80$ & $6.8-6.8$ & $11.1-20.6$ & $0-83.6$ \\
\hline
\end{tabular}

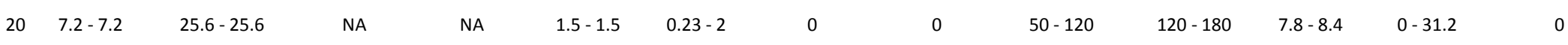




\begin{tabular}{|c|c|c|c|c|c|c|c|c|c|c|c|c|c|}
\hline 21 & $7.1-7.7$ & $27-27$ & $5.3-6.9$ & NA & $0.5-1.5$ & $0.15-1$ & 0 & 0 & $50-50$ & $120-120$ & $7.2-8.4$ & $0-26.1$ & $0-0.6$ \\
\hline 22 & $7.9-8.1$ & $25.7-25.7$ & $0.5-6.4$ & NA & 0 & $0-1.5$ & 0 & 0 & $25-425$ & $180-220$ & $7.8-7.9$ & $0-25.7$ & $0-0.6$ \\
\hline \multicolumn{14}{|c|}{ Queensland } \\
\hline 23 & $7.8-8.4$ & $13.3-24.2$ & $2.8-8.2$ & $464-729$ & $0-0.15$ & $0-0.5$ & 0 & 0 & $120-250$ & $160-240$ & $7.2-8.4$ & $11.7-22.9$ & $0-69.2$ \\
\hline 24 & $7.7-8.3$ & $16-26.2$ & $7.7-11.3$ & $513-780$ & $0-1$ & $0-1$ & 0 & 0 & $120-338$ & $120-240$ & $7.8-7.8$ & $11.1-25.1$ & $0-32.8$ \\
\hline 25 & $8.1-8.2$ & $15.4-24.8$ & $7.2-9.5$ & $303-684$ & $0-0.2$ & $0-0.05$ & 0 & 0 & $120-200$ & $120-180$ & $7.8-7.8$ & $13.8-24.9$ & $0.2-12.8$ \\
\hline 26 & $6.4-7.5$ & $20.1-31.2$ & $2.2-7.6$ & $227-1049$ & $0-1$ & $0-0.15$ & 0 & 0 & $120-250$ & $80-240$ & $6.8-8.4$ & $19.1-28.4$ & $0-155.2$ \\
\hline 27 & $6.1-6.8$ & $20.2-27.5$ & $7.7-8.5$ & $38-41$ & $0-1$ & $0-1$ & 0 & 0 & $0-25$ & $0-80$ & $6.2-6.8$ & $19.2-28.4$ & $0-230.5$ \\
\hline 28 & $7.5-8.6$ & $20.4-29.4$ & $8.1-9$ & $237-729$ & $0-1$ & $0-0.5$ & 0 & 0 & $50-250$ & $180-240$ & $7.8-8.4$ & $16-27.6$ & $0.2-86.2$ \\
\hline 29 & $7.9-8.3$ & $14.8-26.6$ & $6.1-13.5$ & $452-1732$ & $0-0.25$ & $0-0.15$ & 0 & 0 & $120-425$ & $180-240$ & $7.8-8.4$ & $13.8-24.9$ & $0.2-12.8$ \\
\hline 30 & $7.9-8.2$ & $15.6-26$ & $7.4-9.7$ & $371-701$ & $0-0.5$ & $0-0.15$ & 0 & 0 & $120-425$ & $80-240$ & $7.2-7.8$ & $16.4-25.3$ & $0-38.4$ \\
\hline 31 & $6.2-7.6$ & $16.1-28.7$ & $2.7-7.1$ & $310-440$ & $0-2$ & $0-0.15$ & 0 & 0 & $120-120$ & $40-120$ & $6.2-7.8$ & $14.5-24.7$ & $0-28.2$ \\
\hline 32 & $7.9-8.9$ & $17.5-29.2$ & $1.2-9$ & $48-672$ & $0-0$ & $0-0.5$ & 0 & 0 & $120-250$ & $120-240$ & $7.8-8.4$ & $15.7-25.2$ & $0-38.4$ \\
\hline 33 & $7.3-7.5$ & $15.8-25.2$ & $7.8-9.5$ & $160-578$ & $0.1-1$ & $0-1$ & 0 & 0 & $100-120$ & $40-180$ & $7-7.9$ & $13.6-24.9$ & $0-29.6$ \\
\hline 34 & $7.3-8$ & $26.5-27.6$ & $4.1-4.4$ & $370-864$ & $0.1-2$ & $0-0.5$ & 0 & 0 & $120-250$ & $8-240$ & $7.5-19.1$ & $12.2-24.2$ & $0-11.8$ \\
\hline 35 & $7.7-8.2$ & $13-25.2$ & $6-10.2$ & $818-2309$ & $0-0.15$ & $0-0.05$ & 0 & 0 & $250-425$ & $240-240$ & $7.8-8.4$ & $14-25.2$ & $0-48$ \\
\hline 36 & $6.3-7.7$ & $22-30$ & $2.4-7.1$ & $69-278$ & $0-0.15$ & $0-0.15$ & 0 & 0 & $25-75$ & $40-120$ & $6-6.8$ & $20.9-27.8$ & $0.2-74$ \\
\hline 37 & $6.8-8.2$ & $21.9-26.3$ & $5.6-10.2$ & $45-100$ & $0-0.15$ & $0-0.5$ & 0 & 0 & $25-50$ & $40-240$ & $7.2-7.2$ & $19.1-28.3$ & 0 - 126.6 \\
\hline 38 & $7.7-8.9$ & $15.2-25.8$ & $9.4-10.3$ & $57-70$ & $0-0$ & 0 & 0 & 0 & $25-120$ & $40-40$ & $6.8-7.8$ & $14.8-24.7$ & $4.8-14$ \\
\hline 39 & $4.9-7.8$ & $28.7-29.1$ & $5.1-8.2$ & $70-1023$ & $0.15-1$ & $0-0.15$ & 0 & 0 & $0-425$ & $0-80$ & $6.8-19.2$ & $16.1-25.6$ & $0-54.2$ \\
\hline 40 & $7.8-8.2$ & $14.6-22$ & $1.2-7.7$ & $210-432$ & $0-0.1$ & $0-0.5$ & 0 & 0 & $50-120$ & $40-120$ & $6.8-7.2$ & $14.1-22.8$ & $0.2-46.8$ \\
\hline 41 & $7.1-8.2$ & $10-26.9$ & $7.1-7.9$ & $370-590$ & $0-1$ & $0-0.15$ & 0 & 0 & $7-425$ & $8-240$ & $6.8-18$ & $16.1-25.6$ & $0-54.2$ \\
\hline \multicolumn{14}{|c|}{ South Australia } \\
\hline 42 & $6.9-11.3$ & $11.8-20.8$ & $6.9-9.1$ & $1154-2167$ & $0-2$ & $0-1$ & $0-0.5$ & 0 & $25-120$ & $240-240$ & $7.2-8.4$ & $9.8-21.6$ & $0-19.2$ \\
\hline 43 & $6.8-8.3$ & $11.9-20.2$ & $6.7-10.6$ & $622-821$ & $0-1$ & 0 & 0 & 0 & $7-250$ & $180-240$ & $8.4-8.4$ & $9.8-18$ & $0.2-19.2$ \\
\hline 44 & $7.3-8$ & 11.5 - 19.7 & $7.2-24.1$ & $271-385$ & $0-1$ & $0-0.15$ & 0 & 0 & $3-120$ & $40-80$ & $6.8-7.2$ & $8.2-18$ & $0.2-19.2$ \\
\hline \multicolumn{14}{|l|}{ Victoria } \\
\hline 45 & $6.9-7.2$ & $13.4-26.9$ & $5.2-7.3$ & $90-142$ & $0-1$ & $0-0.15$ & 0 & 0 & $50-50$ & $40-80$ & $6.8-8.8$ & $10.1-28.9$ & $0-23.9$ \\
\hline 46 & $6.1-6.7$ & $12-30.1$ & $5-6.8$ & $102-437$ & $0-1$ & $0-0.15$ & 0 & 0 & $50-120$ & $40-40$ & $6.8-7.2$ & $9.9-18.7$ & $6-42$ \\
\hline 47 & $6.7-7.1$ & $13.6-27.3$ & $5.7-7.9$ & $42-54$ & $0-1$ & $0-0.15$ & 0 & 0 & $25-25$ & $0-80$ & $6.8-6.8$ & $9.8-19.9$ & $0.2-45.2$ \\
\hline
\end{tabular}




\begin{tabular}{|c|c|c|c|c|c|c|c|c|c|c|c|c|c|}
\hline 48 & $6.6-7.1$ & $8.3-21.4$ & $6.4-9.6$ & $112-246$ & $0-1$ & $0-0.15$ & 0 & 0 & $50-50$ & $40-40$ & $6.8-6.8$ & $8.8-19.9$ & $2.6-29.8$ \\
\hline 49 & $6.2-6.9$ & $9-23.9$ & $5.9-9.5$ & $217-260$ & $0.15-1$ & $0-1$ & 0 & 0 & $3-50$ & $40-80$ & $6.2-6.8$ & $8.2-19.9$ & $2.6-29.8$ \\
\hline 50 & $6.4-7.5$ & $12.1-25.4$ & $3.8-6.9$ & $400-1774$ & $0-1$ & $0-1$ & 0 & 0 & $7-425$ & $40-120$ & $6.8-7.8$ & $9.7-19.8$ & $5-58.4$ \\
\hline 51 & $6.1-8.3$ & $11-20.5$ & $6-7.2$ & $101-148$ & $0-1$ & 0 & 0 & 0 & $2-50$ & $40-40$ & $6.8-6.8$ & $6.9-17.5$ & $13.6-62.4$ \\
\hline 52 & $6.8-7.5$ & $15-26.6$ & $6.5-7.4$ & $15-686$ & $0-1$ & $0-1$ & 0 & 0 & $50-120$ & $40-120$ & $6.8-7.2$ & $10.1-21$ & $0.4-37.4$ \\
\hline 53 & $6.4-7.8$ & $9.8-26.3$ & $5-7.9$ & $159-2550$ & $0-1$ & $0-1$ & 0 & 0 & $0-425$ & $40-240$ & $6.8-7.8$ & $11.4-20.8$ & $6-37.8$ \\
\hline 54 & $7-7.4$ & $12.3-22.2$ & $5-6.9$ & $9-780$ & $0-1$ & $0-0.15$ & 0 & 0 & $50-120$ & $40-120$ & $6.8-68$ & $11.9-20.8$ & $6.6-20.4$ \\
\hline 55 & $5.9-7.1$ & $13.3-22.5$ & $3.1-4.9$ & $509-1231$ & $0.15-1$ & $0-0.15$ & 0 & 0 & $120-120$ & $40-120$ & $6.2-7.2$ & $11.1-19.2$ & $12.2-48.3$ \\
\hline 56 & $6.1-7.1$ & $14.1-20.4$ & $4.7-5.7$ & $176-242$ & $0-1$ & $0-1$ & 0 & 0 & $50-120$ & $40-80$ & $6.8-6.8$ & $11-19.5$ & $11.4-45.8$ \\
\hline 57 & $6-7.1$ & $13.2-19.2$ & $3.1-6.9$ & $266-2089$ & $0.15-1$ & $0-0.15$ & 0 & 0 & $120-425$ & $40-240$ & $6.8-68$ & $11.2-20.1$ & $1.2-51.8$ \\
\hline 58 & $6.8-7.9$ & $10.1-18.8$ & $4.4-6$ & $125-600$ & $0.15-1$ & $0-0.3$ & 0 & 0 & $50-120$ & $80-120$ & $6.8-7.8$ & $11.6-20.8$ & $6.6-31.4$ \\
\hline 59 & $6.9-8$ & $11-19.9$ & $5.9-7.8$ & $167-1123$ & $0.15-1$ & $0-0.15$ & 0 & 0 & $50-250$ & $80-240$ & $6.8-8.4$ & $10.5-19.6$ & $3.2-39.4$ \\
\hline 60 & $6.9-8$ & $11.3-23.9$ & $7.2-8.8$ & $1384-2129$ & $0-1$ & $0-0.15$ & 0 & 0 & $120-250$ & $240-240$ & $7.8-8.5$ & 10.6 - 19.8 & $3.2-39.4$ \\
\hline 61 & $7-8.5$ & $11.6-24.5$ & $7-9.7$ & $211-572$ & $0-1$ & $0-0.15$ & 0 & 0 & $50-120$ & $80-240$ & $7.2-8.4$ & $10.7-20.1$ & $1.2-17.8$ \\
\hline 62 & $5.6-7.3$ & $10.5-22.3$ & $4.4-10.2$ & $375-3120$ & $0-1$ & $0-0.15$ & 0 & 0 & $25-425$ & $240-240$ & $6.8-8.4$ & $10.6-19.7$ & $1.4-6.4$ \\
\hline 63 & $6.1-7.1$ & $6-16.7$ & $4.4-9.7$ & $76-151$ & $0-1$ & $0-0.15$ & 0 & 0 & $0-25$ & $40-40$ & $6.2-6.8$ & $7.1-17.5$ & $3-14.4$ \\
\hline \multicolumn{14}{|c|}{ Western Australia } \\
\hline 64 & $7.2-8$ & $15.4-23$ & $5.2-11.1$ & $485-694$ & $0.15-1$ & $0-1$ & $0-1$ & 0 & $120-120$ & $40-180$ & $7-7.8$ & $12.8-21.7$ & $5.2-75.8$ \\
\hline 65 & $7.4-7.7$ & $16.7-22.4$ & $3.3-10.1$ & $394-905$ & $0.15-2$ & $0-1$ & 0 & 0 & $50-120$ & $80-240$ & $6.2-7.2$ & $11.9-22.1$ & $0-64.1$ \\
\hline 66 & $7.2-9.2$ & $15.2-26.6$ & $5.6-13$ & $107-1282$ & $0-1.5$ & $0-1$ & 0 & 0 & $120-250$ & $80-120$ & $7.2-7.2$ & $12.8-21.7$ & $5.2-75.8$ \\
\hline 67 & $7.3-9.2$ & $16-29.4$ & $8.1-16.4$ & $148-767$ & $0.3-1$ & $1-2$ & 0 & 0 & $120-120$ & $80-180$ & $7.2-7.2$ & $12.4-21.7$ & $5.2-154.4$ \\
\hline 68 & $7.1-8.2$ & $12.5-21.4$ & $7.9-10.1$ & $225-314$ & $0-2$ & $0-1$ & 0 & 0 & $50-120$ & $40-40$ & $6.8-7.2$ & $11.8-22.1$ & $0-156.9$ \\
\hline 69 & $7.1-7.5$ & $19.9-26.7$ & $4.5-10.8$ & $146-865$ & $0-2$ & $0-1$ & 0 & 0 & $50-250$ & $80-240$ & $6.2-7.8$ & $14.6-25.5$ & $0-33.2$ \\
\hline 70 & $6.9-7.9$ & $18.6-26.5$ & $2.1-8.5$ & $547-696$ & $0-1$ & $0-1$ & 0 & 0 & $120-120$ & $40-80$ & $6.2-7.2$ & $14.9-25.3$ & $0-29.4$ \\
\hline 71 & $6.9-7.6$ & $19.8-27.5$ & $6.1-7.6$ & 434 - 918 & $0.15-2$ & $0-1$ & 0 & 0 & $25-425$ & $80-180$ & $7.2-7.8$ & $14.9-25.3$ & $0-35.6$ \\
\hline 72 & $7.3-7.9$ & $19.3-25.4$ & $7-7.3$ & $146-665$ & $0-1$ & $0.15-1$ & 0 & 0 & $50-120$ & $40-120$ & $6.8-7.2$ & $14.6-24.1$ & $0-33.2$ \\
\hline 73 & $7-8$ & $12.2-21.7$ & $6-10.6$ & $248-309$ & $0.15-5$ & $0-1$ & 0 & 0 & $3-50$ & $40-40$ & $6.8-7.2$ & $12.1-21.7$ & $6.7-70$ \\
\hline
\end{tabular}

Laboratory Blank

$\begin{array}{lllllll}74 & 8.4-8.8 & 21.7-22.1 & 5.2-7.6 & 0-2 & 0 & 0\end{array}$

$0 \quad 0$

$25-25$

$6.2-7.8$

NA

NA 
Table S3. Transition for compounds using ESI positive mode.

\begin{tabular}{|c|c|c|}
\hline Compound & $\begin{array}{c}\text { Precursor Ion } \\
(\mathbf{m} / \mathbf{z})\end{array}$ & $\begin{array}{c}\text { Product Ion } \\
(\mathbf{m} / \mathbf{z})\end{array}$ \\
\hline Atenolol 1 & 267.2 & 145.1 \\
\hline Atenolol 2 & 267.2 & 190.2 \\
\hline Atenolol-D7 & 274.1 & 145.1 \\
\hline Paracetamol & 152.1 & 110.1 \\
\hline Paracetamol- $-{ }^{15} \mathrm{~N}^{13} \mathrm{C}$ & 155 & 111 \\
\hline Sulfamethoxazole 1 & 254 & 156.1 \\
\hline Sulfamethoxazole 2 & 254 & 92 \\
\hline Sulfamethoxazole-D4 & 258.1 & 160.1 \\
\hline Caffeine 1 & 195 & 138.1 \\
\hline Caffeine 2 & 195 & 110.1 \\
\hline Caffeine-D9 & 204.1 & 144.2 \\
\hline Trimethoprim 1 & 291.1 & 230.2 \\
\hline Trimethoprim 2 & 291.1 & 261.1 \\
\hline Trimethoprim-D9 & 300.3 & 234.2 \\
\hline tris(2-Chloroethyl) phosphate (TCEP) 1 & 284.9 & 223 \\
\hline tris(2-Chloroethyl) phosphate (TCEP) 2 & 284.9 & 62.9 \\
\hline Phenytoin 1 & 253.1 & 182.1 \\
\hline Phenytoin 2 & 253.1 & 104.1 \\
\hline Phenytoin -D10 & 263.1 & 192.2 \\
\hline Carbamazepine 1 & 237 & 194.2 \\
\hline Carbamazepine 2 & 237 & 192.1 \\
\hline Carbamazepine-D10 & 247.1 & 204.3 \\
\hline Fluoxetine 1 & 310 & 44.1 \\
\hline Fluoxetine 2 & 310 & 148.2 \\
\hline Fluoxetine-D5 & 315.1 & 44.2 \\
\hline Enalapril 1 & 377.1 & 234.1 \\
\hline Enalapril 2 & 377.1 & 91.1 \\
\hline Enalapril-D5 & 382.2 & 239.2 \\
\hline Risperidone 1 & 411.1 & 191.2 \\
\hline Risperidone 2 & 411.3 & 110 \\
\hline Risperidone-D4 & 415.1 & 195.2 \\
\hline Atrazine 1 & 216 & 174.2 \\
\hline Atrazine 2 & 216 & 96.1 \\
\hline Atrazine-D5 & 221.3 & 179.1 \\
\hline Linuron 1 & 249 & 182.2 \\
\hline Linuron 2 & 249 & 160.1 \\
\hline Linuron-D6 & 255 & 160.1 \\
\hline Atorvastatin 1 & 559.1 & 440.1 \\
\hline Atorvastatin 2 & 559.1 & 250.3 \\
\hline Atorvastatin-D5 & 564.2 & 445.4 \\
\hline o-Hydroxy atorvastatin 1 & 575.2 & 440.2 \\
\hline o-Hydroxy atorvastatin 2 & 575.2 & 466.1 \\
\hline o-Hydroxy atorvastatin D5 & 580.2 & 445.1 \\
\hline
\end{tabular}




\begin{tabular}{|c|c|c|}
\hline Compound & $\begin{array}{c}\text { Precursor Ion } \\
(\mathbf{m} / \mathbf{z})\end{array}$ & $\begin{array}{c}\text { Product Ion } \\
(\mathrm{m} / \mathrm{z})\end{array}$ \\
\hline p-Hydroxy atorvastatin 1 & 575.2 & 440.2 \\
\hline p-Hydroxy atorvastatin 2 & 575.2 & 466.1 \\
\hline p-Hydroxy atorvastatin D5 & 580.2 & 445.1 \\
\hline Omeprazole 1 & 346.2 & 198.2 \\
\hline Omeprazole 2 & 346.2 & 136.1 \\
\hline Omeprazole D3 & 349.2 & 198 \\
\hline Clozapine 1 & 327.1 & 270.2 \\
\hline Clozapine 2 & 327.1 & 192.1 \\
\hline Clozapine_D4 & 331.2 & 272 \\
\hline Amtriptyline 1 & 278.2 & 233 \\
\hline Amtriptyline 2 & 278.2 & 117.1 \\
\hline Amtriptyline-D6 & 284.4 & 233.1 \\
\hline DEET 1 & 192.2 & 119 \\
\hline DEET 2 & 192.2 & 108.9 \\
\hline DEET-D7 & 199.2 & 126.1 \\
\hline Primidone 1 & 219.2 & 162.2 \\
\hline Primidone 2 & 219.2 & 119 \\
\hline Primidone-D5 & 224.2 & 167 \\
\hline Verapamil 1 & 455.4 & 165.1 \\
\hline Verapamil 2 & 455.4 & 150 \\
\hline Verapamil-D6 & 461.4 & 165.2 \\
\hline Triamterene 1 & 254.2 & 237 \\
\hline Triamterene 2 & 254.2 & 104 \\
\hline Triamterene-D5 & 259.2 & 242.2 \\
\hline Propylparaben 1 & 181.2 & 139.1 \\
\hline Propylparaben 2 & 181.2 & 121 \\
\hline Meprobamate 1 & 218.9 & 158.2 \\
\hline Meprobamate 2 & 218.9 & 115.1 \\
\hline Meprobamate-D3 & 221.9 & 161.2 \\
\hline Hydroxyzine 1 & 375.3 & 201.1 \\
\hline Hydroxyzine 2 & 375.3 & 165.1 \\
\hline Hydroxyzine-D8 & 383.3 & 201.1 \\
\hline Methotraxate 1 & 455.2 & 308.2 \\
\hline Methotraxate 2 & 455.2 & 175 \\
\hline Chlorpyrifos 1 & 349.9 & 197.9 \\
\hline Chlorpyrifos 2 & 349.9 & 115 \\
\hline Diazinon 1 & 305.1 & 169.1 \\
\hline Diazinon 2 & 305.1 & 115 \\
\hline Simazine 1 & 202.1 & 132.1 \\
\hline Simazine 2 & 202.1 & 124.1 \\
\hline Simazine-D10 & 212.2 & 137.1 \\
\hline Trifluralin 1 & 336.2 & 236.1 \\
\hline Trifluralin 2 & 336.2 & 251.8 \\
\hline Trifluralin-D14 & 350.2 & 238 \\
\hline Diazepam 1 & 285.1 & 193.1 \\
\hline
\end{tabular}




\begin{tabular}{lcc}
\hline Compound & $\begin{array}{c}\text { Precursor Ion } \\
(\mathbf{m} / \mathbf{z})\end{array}$ & $\begin{array}{c}\text { Product Ion } \\
(\mathbf{m} / \mathbf{z})\end{array}$ \\
\hline Diazepam 2 & 285.1 & 154.2 \\
Diazepam-D5 & 290.1 & 198.1 \\
\hline
\end{tabular}


Table S4. Transitions for compounds using ESI negative mode.

\begin{tabular}{lcc}
\hline Compound & $\begin{array}{c}\text { Precursor Ion } \\
(\mathbf{m} / \mathbf{z})\end{array}$ & $\begin{array}{c}\text { Product Ion } \\
(\mathbf{m} / \mathbf{z})\end{array}$ \\
\hline Ketoprofen & 252.8 & 208.8 \\
Ketoprofen-D3 & 255.6 & 211.7 \\
Naproxen 1 & 228.9 & 184.6 \\
Naproxen 2 & 228.9 & 169.8 \\
Naproxen-D3 & 231.9 & 187.8 \\
Ibuprofen 1 & 204.9 & 160.8 \\
Ibuprofen 2 & 204.9 & 158.8 \\
Ibuprofen-D3 & 208 & 163.9 \\
Gemfibrozil 1 & 248.9 & 120.8 \\
Gemfibrozil 2 & 248.9 & 126.8 \\
Gemfibrozil-D6 & 254.9 & 120.9 \\
Triclosan & 286.6 & 35 \\
Triclosan-D3 & 289.7 & 34.9 \\
Simvastatin-hydroxyacid 1 & 318.9 \\
Simvastatin-hydroxyacid 2 & 435.1 & 114.9 \\
Simvastatin-hydroxyacid-D6 & 435.1 & 319 \\
Simvastatin 1 & 441.1 & 114.9 \\
Simvastatin 2 & 399 & 282.8 \\
Simvastatin-D6 & 399 & 121.1 \\
Salicilic acid 1 & 405.4 & 92.8 \\
Salicilic acid 2 & 136.9 & 65 \\
Salicilic acid-D6 & 136.9 & 96.9 \\
Triclocarban 1 & 140.9 & 159.8 \\
Triclocarban 2 & 312.9 & 125.7 \\
Triclocarban-D4 & 312.9 & 159.8 \\
Propylparaben 1 & 317 & 135.7 \\
Propylparaben 2 & 179 & 136.9 \\
2-Phenylphenol 1 & 114.8 \\
2-Phenylphenol 2 & 179 & 140.8 \\
\hline & 168.9 & \\
\hline
\end{tabular}

